\title{
Complex Metal Hydrides for Hydrogen, Thermal and Electrochemical Energy Storage
}

\author{
Kasper T. Møller ${ }^{1}$ (D), Drew Sheppard ${ }^{1,2}$, Dorthe B. Ravnsbæk ${ }^{3}$ (i) , Craig E. Buckley ${ }^{2}$,

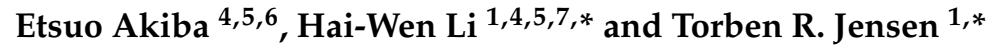 \\ 1 Interdisciplinary Nanoscience Center (iNANO) and Department of Chemistry, Aarhus University, \\ DK-8000 Aarhus, Denmark; kaspertm@inano.au.dk (K.T.M.); drew.sheppard@gmail.com (D.S.) \\ 2 Department of Physics and Astronomy, Fuels and Energy Technology Institute, Curtin University, \\ GPO Box U1987, Perth, WA 6845, Australia; C.Buckley@curtin.edu.au \\ 3 Department of Physics, Chemistry and Pharmacy, University of Southern Denmark, Campusvej 55, \\ 5230 Odense M, Denmark; dbra@sdu.dk \\ 4 International Research Center for Hydrogen Energy, Kyushu University, Fukuoka 819-0395, Japan; \\ akiba.etsuo.297@m.kyushu-u.ac.jp \\ 5 WPI International Institute for Carbon Neutral Energy Research (WPI-I2CNER), Kyushu University, \\ Fukuoka 819-0395, Japan \\ 6 Department of Mechanical Engineering, Faculty of Engineering, Kyushu University, \\ Fukuoka 819-0395, Japan \\ 7 Kyushu University Platform of Inter/Transdisciplinary Energy Research, Fukuoka 819-0395, Japan \\ * Correspondence: li.haiwen.305@m.kyushu-u.ac.jp (H.-W.L.); trj@chem.au.dk (T.R.J.) \\ Academic Editor: Haolin Tang \\ Received: 18 September 2017; Accepted: 12 October 2017; Published: 18 October 2017
}

\begin{abstract}
Hydrogen has a very diverse chemistry and reacts with most other elements to form compounds, which have fascinating structures, compositions and properties. Complex metal hydrides are a rapidly expanding class of materials, approaching multi-functionality, in particular within the energy storage field. This review illustrates that complex metal hydrides may store hydrogen in the solid state, act as novel battery materials, both as electrolytes and electrode materials, or store solar heat in a more efficient manner as compared to traditional heat storage materials. Furthermore, it is highlighted how complex metal hydrides may act in an integrated setup with a fuel cell. This review focuses on the unique properties of light element complex metal hydrides mainly based on boron, nitrogen and aluminum, e.g., metal borohydrides and metal alanates. Our hope is that this review can provide new inspiration to solve the great challenge of our time: efficient conversion and large-scale storage of renewable energy.
\end{abstract}

Keywords: complex metal hydrides; thermal energy storage; hydrogen storage; solid-state electrolytes; electrodes; fuel cell

\section{Introduction}

The ultimate challenge of our time is the development of an environmentally friendly energy system based on sustainable renewable energy to replace our fossil fuel dependency. Fossil fuels are burnt and energy release is accompanied by release of carbon dioxide $\left(\mathrm{CO}_{2}\right)$, nitrogen oxides $\left(\mathrm{NO}_{\mathrm{x}}\right)$, particles etc. and may locally lead to extreme air pollution and smog while climate changes are observed globally. Hence, the great challenge of our time is efficient conversion and large-scale storage of renewable energy for days, weeks, and maybe months [1]. However, renewable energy sources generally vary significantly over time and place [2]. Thus, the realization of this scenario calls for a range of novel ideas, technologies, and a paradigm shift in design and development of novel energy materials with new functionalities. Incremental improvement of known materials never changes the 
world, but just one new material may, since novel materials often form the basis for technological paradigm shifts. The chemistry of hydrogen is very diverse and a wide range of novel hydrides have been discovered during the past decade with a rich and fascinating structural chemistry and a range of useful properties, e.g., energy storage, which is the topic of this review.

Renewable energy occurs mainly as heat from the sun or electricity from sun or wind. Electricity can be used directly, stored in a battery, or used to split water to hydrogen and oxygen, see Figure 1.

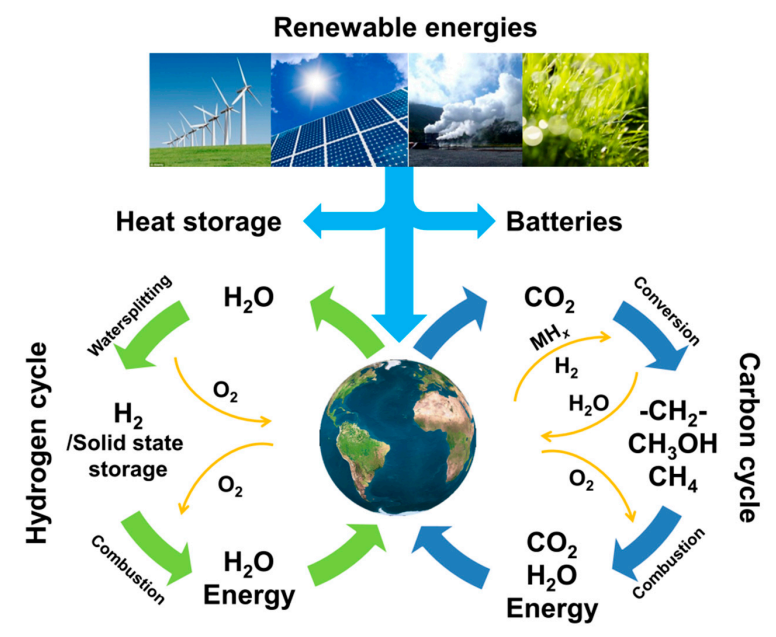

Figure 1. Illustration of a sustainable global energy system based on energy storage in either batteries, as heat storage, using hydrogen as a carrier (left) or a carbon neutral cycle (right). Modified figure from [1].

Hydrogen $\left(\mathrm{H}_{2}\right)$, is the lightest element of all and also has some unique properties among known substances, e.g., the highest gravimetric energy density, the fastest diffusion speed in air, and a low density both as a gas and liquid. The latter makes hydrogen challenging to store in a dense manner. Figure 1 illustrates that maybe in the future, carbon dioxide from the atmosphere is reacted with hydrogen to create 'carbon neutral' hydrocarbons or carbohydrates. Oxidation of such hydrocarbons/carbohydrates will not increase the carbon dioxide level in the atmosphere. Sustainability means that all material cycles are closed, including our energy system. Therefore, all materials that we use must be reused as illustrated in Figure 1.

This review reveals metal hydrides as a diverse class of materials with a range of compositions, structures and properties towards multi-functionality. The focus is on light elemental hydrides, consisting mainly of boron, nitrogen or aluminum, which may be used for storage of hydrogen, solar heat or as novel battery materials. It is hoped that this review will provide new inspiration to create new materials and technologies for efficient conversion and large-scale storage of renewable energy.

\section{Complex Metal Hydrides for High-Density Hydrogen Storage}

Complex metal hydrides (CMHs) formed by light elements, such as boron, nitrogen, or aluminum often have extreme hydrogen densities but also poor thermodynamic and kinetic properties and limited reversibility [1-4]. Initially, the discovery of reversibility in titanium-catalyzed $\mathrm{NaAlH}_{4}$ initiated a paradigm shift in hydrogen storage research towards complex anions [5]. Hence, research was extended to include metal borohydrides, e.g., $\mathrm{LiBH}_{4}$ and nitrogen-based complex hydrides, e.g., $\mathrm{LiNH}_{2}$ [6-8]. The complex hydride anions consist mainly of covalent bonds with well-defined directionality, whereas ionic bonding dominates in the solid state between the complex anions and counter cations, e.g., in $\mathrm{LiBH}_{4}, \mathrm{NaBH}_{4}$, and $\mathrm{NaAlH}_{4}$. Solid state $\mathrm{CMHs}$ have high volumetric and gravimetric hydrogen densities (see Table 1), which makes them interesting as hydrogen storage materials. However, the poor thermodynamic and kinetic properties only allow hydrogen release and 
uptake at elevated temperatures and pressures, which makes them unsuitable for portable applications. The hydrogen release pathway from complex hydrides is complicated compared to metallic and ionic hydrides, and thus remains not fully understood.

Amide-hydride composite systems, e.g., $\mathrm{LiNH}_{2}-\mathrm{LiH}$, has been investigated as possible candidates for hydrogen storage [7]. The $\mathrm{LiNH}_{2}-\mathrm{LiH}$ composite has a high calculated hydrogen content of $\rho_{\mathrm{m}}=10.5 \mathrm{wt} \%$ $\mathrm{H}_{2}$ and releases hydrogen according to reaction scheme (1).

$$
\mathrm{LiNH}_{2}(\mathrm{~s})+2 \mathrm{LiH}(\mathrm{s}) \leftrightarrow \mathrm{Li}_{2} \mathrm{NH}(\mathrm{s})+\mathrm{LiH}(\mathrm{s})+\mathrm{H}_{2}(\mathrm{~g}) \leftrightarrow \mathrm{Li}_{3} \mathrm{~N}(\mathrm{~s})+2 \mathrm{H}_{2}(\mathrm{~g})
$$

The decomposition reaction initiates at $T=180^{\circ} \mathrm{C}$, which is lower than those of the individual reactants, i.e., $300{ }^{\circ} \mathrm{C}$ for $\mathrm{LiNH}_{2}$ and $600{ }^{\circ} \mathrm{C}$ for $\mathrm{LiH}$ [7]. Thus, similar composite systems have been considered [9-13], e.g., $\mathrm{Mg}\left(\mathrm{NH}_{2}\right)_{2}-2 \mathrm{LiH}\left(5.6 \mathrm{wt} \% \mathrm{H}_{2}\right)$ with suitable thermodynamic properties $\left(\Delta H_{\text {des }}=39 \mathrm{~kJ} \mathrm{~mol}^{-1} \mathrm{H}_{2}, \Delta S_{\text {des }}=112 \mathrm{~J} \mathrm{~K}^{-1} \mathrm{~mol}^{-1} \mathrm{H}_{2}\right)$, i.e., dehydrogenation may occur below $90{ }^{\circ} \mathrm{C}$ at $p\left(\mathrm{H}_{2}\right)=1$ bar [14]. However, experimental results reveal that $T>180{ }^{\circ} \mathrm{C}$ is required to achieve hydrogen release [9]. Addition of $\mathrm{CaH}_{2}(8 \mathrm{~mol} \%)$ catalyzes the reaction and decreases the activation energy, i.e., the decomposition begins at $78{ }^{\circ} \mathrm{C}$ [15]. Generally, the dehydrogenation of amide-hydride systems suffer from sluggish kinetics that might be caused by interface reactions, nucleation/nuclei growth, and/or diffusion processes. Mechanical milling was found to be effective in increasing the dehydrogenation kinetics, due to the reduced grain size and increased homogeneous distribution of amide and hydride particles $[16,17]$. An effective catalyst may significantly improve the kinetics. Recently, $\mathrm{K}_{2}\left[\mathrm{Zn}\left(\mathrm{NH}_{2}\right)_{4}\right]$ was synthesized by mechanochemical milling and the composite $\mathrm{K}_{2}\left[\mathrm{Zn}\left(\mathrm{NH}_{2}\right)_{4}\right]-8 \mathrm{LiH}$ showed release of $4.2 \mathrm{wt} \% \mathrm{H}_{2}$ below $400{ }^{\circ} \mathrm{C}$ [18-20]. Remarkably, the composite may be fully hydrogenated in $30 \mathrm{~s}$ at $230{ }^{\circ} \mathrm{C}$ and $p\left(\mathrm{H}_{2}\right)=50$ bar [18-20]. The $\mathrm{LiAl}\left(\mathrm{NH}_{2}\right)_{4}-4 \mathrm{LiH}$ desorbs $5.0 \mathrm{wt} \% \mathrm{H}_{2}$ at $130{ }^{\circ} \mathrm{C}$ [21]. However, the instability of $\mathrm{LiAl}(\mathrm{NH})_{2}$, one of the desorption products, prevents rehydrogenation [21]. Metal amides and metal hydroxides may also form solid solutions, such as in the $\mathrm{NaNH}_{2}-\mathrm{NaOH}$ system [22].

Table 1. Properties of selected light element complex metal hydrides [23,24]. $M=$ molar mass; $\rho=$ volumetric mass density; $\rho_{\mathrm{m}}=$ gravimetric hydrogen density; $\rho_{V}=$ volumetric hydrogen density; $\Delta H_{\mathrm{dec}}=$ decomposition enthalpy; $T(1$ bar $)=$ equilibrium temperature at $p\left(\mathrm{H}_{2}\right)=1$ bar; $T_{\mathrm{dec}}=$ decomposition temperature.

\begin{tabular}{|c|c|c|c|c|c|c|c|c|}
\hline & $\begin{array}{c}M \\
(\mathrm{~g} / \mathrm{mol})\end{array}$ & $\rho(\mathrm{g} / \mathrm{mL})$ & $\rho_{\mathrm{m}}\left(\mathrm{wt} \% \mathrm{H}_{2}\right)$ & $\rho_{V}\left(\mathrm{~g} \mathrm{H}_{2} / \mathrm{L}\right)$ & $\begin{array}{c}\Delta H_{\mathrm{dec}} \\
(\mathrm{kJ} / \mathrm{mol})\end{array}$ & $\begin{array}{c}T(1 \text { bar }) \\
\left({ }^{\circ} \mathrm{C}\right)\end{array}$ & $T_{\text {dec }}\left({ }^{\circ} \mathrm{C}\right)$ & Ref. \\
\hline $\mathrm{LiBH}_{4}$ & 21.78 & 0.66 & 18.4 & 122.5 & 74 & 370 & $\sim 400$ & [25] \\
\hline $\mathrm{NaBH}_{4}$ & 37.83 & 1.07 & 10.8 & 115.6 & 108 & 534 & $\sim 500$ & [26] \\
\hline $\mathrm{LiAlH}_{4}$ & 37.95 & 0.92 & 10.6 & 97.5 & -10 & - & $\sim 150^{\mathrm{a}}$ & [27] \\
\hline $\mathrm{Li}_{3} \mathrm{AlH}_{6}$ & 53.85 & 1.02 & 11.2 & 114.2 & 25 & $-81^{c}$ & $\sim 200^{a}$ & [27] \\
\hline $\mathrm{NaAlH}_{4}$ & 54.00 & 1.28 & 7.3 & 93.4 & 33.1 & 18 & $\sim 230^{\mathrm{a}}$ & [28] \\
\hline $\mathrm{Na}_{3} \mathrm{AlH}_{6}$ & 102.00 & 1.45 & 5.9 & 85.6 & 49.0 & 103 & $\sim 275^{\mathrm{a}}$ & [28] \\
\hline $\mathrm{LiNH}_{2}$ & 22.96 & 1.18 & 8.8 & 103.6 & $67^{b}$ & - & $\sim 300$ & [29-31] \\
\hline
\end{tabular}

${ }^{a}$ Not catalysed. Decomposition temperatures strongly depend on the physical conditions for the measurement and the published data scatter significantly; ${ }^{\mathrm{b}}$ Reported for the $\mathrm{LiNH}_{2}-\mathrm{LiH}$ system; ${ }^{\mathrm{c}}$ Calculated based on the van't Hoff equation using $\Delta S=130 \mathrm{~J} /(\mathrm{mol} \mathrm{K})$.

\subsection{Complex Aluminum Hydrides}

\subsubsection{Aluminum Hydride}

Aluminum hydride $\left(\mathrm{AlH}_{3}\right.$, alane), is a promising hydrogen-storage material based on thegravimetric and volumetric hydrogen density of $\rho_{\mathrm{m}}=10.1$ wt $\% \mathrm{H}_{2}$ and $\rho_{\mathrm{V}}=149 \mathrm{~g} \mathrm{H}_{2} / \mathrm{L}$, respectively. Additionally, alane has a low hydrogen desorption temperature and fast desorption kinetics, whilst aluminum is abundant [32]. Alane is thermodynamically unstable at room temperature due to a positive Gibbs free energy of formation, $\Delta G_{f}{ }^{\circ}=46.5 \mathrm{~kJ} / \mathrm{mol}$, however, the crystalline $\alpha-\mathrm{AlH}_{3}$ is kinetically stable at room temperature [33-35]. Alane was first synthesized in its pure form in 
1947 [36]. Since then, a variety of six polymorphs of alane has been discovered $(\alpha, \alpha, \beta, \gamma, \delta$ and $\varepsilon)$ [37]. The obtained polymorph is entirely dependent on the chosen synthesis route [38]. The structures of $\alpha-, \alpha^{\prime}-, \beta-$, and $\gamma-\mathrm{AlH}_{3}$ consist of corner-sharing $\mathrm{AlH}_{6}$ octahedra whereas $\gamma-\mathrm{AlH}_{3}$ also possesses edge-sharing $\mathrm{AlH}_{6}$ octahedra [37,39-43].

Alane can be produced directly from the elements by hydrogenation of aluminum. However, this synthesis method is impractical as it requires a hydrogen pressure above $25 \mathrm{kbar}$ at room temperature [44]. Another synthesis method is by mechanochemical treatment at liquid nitrogen temperature (cryomilling, $T=-196^{\circ} \mathrm{C}$ ) where a thermodynamically spontaneous metathesis reaction, $\Delta G_{r}{ }^{\circ}=-191 \mathrm{~kJ} / \mathrm{mol}$, between $\mathrm{AlCl}_{3}$ and $\mathrm{LiAlH}_{4}$ occurs (see reaction scheme (2)), producing several polymorphs of alane $\left(\alpha, \alpha^{\prime}, \beta\right.$, and $\left.\gamma-\mathrm{AlH}_{3}\right)[40,45,46]$.

$$
\mathrm{AlCl}_{3}(\mathrm{~s})+3 \mathrm{LiAlH}_{4}(\mathrm{~s}) \rightarrow 3 \mathrm{LiCl}(\mathrm{s})+4 \mathrm{AlH}_{3}(\mathrm{~s})
$$

Furthermore, ball milling of $\mathrm{AlCl}_{3}$ and $\mathrm{LiAlH}_{4}$ at room temperature under hydrogen pressure $\left(p\left(\mathrm{H}_{2}\right)>210\right.$ bar) only leads to formation of $\alpha-\mathrm{AlH}_{3}$ [47]. A solid state reaction is facilitated by thermal treatment at $T \sim 75^{\circ} \mathrm{C}$ followed by solvent extraction of $\mathrm{LiCl}$ [48]. The monomeric alane can also be stabilized as a solvate $\mathrm{R} \cdot \mathrm{AlH}_{3}\left(\mathrm{R}=\mathrm{Et}_{2} \mathrm{O}\right.$, amines or tetrahydrofuran (THF)) by reaction in donating solvents such as ethers or amines [49,50]. Subsequently, the solvent can be removed from the $\mathrm{AlH}_{3}$ adduct by heating in vacuum. Alane readily reacts with metal hydrides to form other complex hydrides [51], e.g., $\mathrm{NaAlH}_{4}$, which will be discussed in the next section.

\subsubsection{Metal Alanates}

The potential of complex aluminum hydrides was seriously established with the discovery of titanium-catalyzed $\mathrm{NaAlH}_{4}$ by Bogdanović in 1997 [5]. The system shows a reversible capacity approximately twice of any of the conventional metal hydrides [52]. The complex aluminum hydrides are based on the tetrahydridoaluminate(1-) or hexahydridoaluminate(3-) complex anion, $\mathrm{AlH}_{4}{ }^{-}$or $\mathrm{AlH}_{6}{ }^{3-}$, respectively, which is commonly denoted alanates.

In the 1960s it was discovered that a range of alkali metal alanates can be prepared through direct hydrogenation of the alkali metal hydride $(\mathrm{MH}, \mathrm{M}=\mathrm{Li}, \mathrm{Na}, \mathrm{K}, \mathrm{Cs})$ and aluminum either in the solid state or in a solvent-mediated reaction $[53,54]$. The reaction is commonly described as a two-step reaction $[55,56]$, see reaction schemes (3) and (4)

$$
\begin{gathered}
3 \mathrm{MH}(\mathrm{s})+\mathrm{Al}(\mathrm{s})+3 / 2 \mathrm{H}_{2}(\mathrm{~g}) \leftrightarrow M_{3} \mathrm{AlH}_{6}(\mathrm{~s}) \\
M_{3} \mathrm{AlH}_{6}(\mathrm{~s})+2 \mathrm{Al}(\mathrm{s})+3 \mathrm{H}_{2}(\mathrm{~g}) \leftrightarrow 3 \mathrm{MAlH}_{4}(\mathrm{~s})
\end{gathered}
$$

However, the detailed reaction mechanism for different metal alanates is debatable and other intermediates may be involved $[55,57]$.

$\mathrm{LiAlH}_{4}\left(\rho_{\mathrm{m}}=10.5 \mathrm{wt} \% \mathrm{H}_{2}\right)$ was synthesized in the late 1940 s and is widely used as a reducing agent in organic chemistry [58], but it attained increased attention as a hydrogen storage material with the discovery of the titanium-catalyzed $\mathrm{NaAlH}_{4}$. Thermolysis of $\mathrm{LiAlH}_{4}$ is initiated by the melting of $\mathrm{LiAlH}_{4}, T_{\mathrm{mp}}\left(\mathrm{LiAlH}_{4}\right)=125{ }^{\circ} \mathrm{C}$ [23], which subsequently decomposes into solid $\mathrm{Li}_{3} \mathrm{AlH}_{6}$ and $\mathrm{Al}$ accompanied by an exothermic release of hydrogen gas in the temperature range $150-220^{\circ} \mathrm{C}[59,60]$. The exothermic decomposition in this first step hinders the full reversibility of the system. The second decomposition step occurs around $190-260^{\circ} \mathrm{C}$ as an endotherm [61,62]. Ball milling metal alanates tends to lower the decomposition temperature as particle size is reduced and defects are introduced. However, $\mathrm{LiAlH}_{4}$ often decomposes during milling with additives, e.g., $\mathrm{TiCl}_{3}, \mathrm{VCl}_{3}$, and $\mathrm{Fe}$ [63-66]. Furthermore, addition of $\mathrm{TiCl}_{3}$ only reduces the decomposition temperature but does not enable rehydrogenation [67]. A way to overcome the energy barrier preventing rehydrogenation of $\mathrm{LiAlH}_{4}$ is to use a solvent-mediated synthesis route, hence $\mathrm{LiH}$ and $\mathrm{Al}$ stirred in, e.g., $\mathrm{THF}$ or $\mathrm{Me}_{2} \mathrm{O}$ and apply hydrogen pressure as low as $p\left(\mathrm{H}_{2}\right)>10$ bar $[68,69]$. 
Sodium alanate, $\mathrm{NaAlH}_{4}\left(\rho_{\mathrm{m}}=7.4 \mathrm{wt} \% \mathrm{H}_{2}\right)$ is the most investigated metal alanate with moderate rehydrogenation conditions of titanium-catalyzed $\mathrm{NaAlH}_{4}\left(\right.$ at $T=170{ }^{\circ} \mathrm{C}, p\left(\mathrm{H}_{2}\right)=150$ bar) [5]. However, the useful capacity is low $\left(5.6 \mathrm{wt} \% \mathrm{H}_{2}\right)$ and not ideal for consideration in mobile applications. Thus, a tremendous effort has been carried out in research to tailor the system, e.g., by addition of dopants or nanoconfinement [70-77]. Furthermore, $\mathrm{NaAlH}_{4}$ has also been widely used as a precursor in metathesis reactions to synthesize new metal alanate compounds, e.g., $\mathrm{Mg}\left(\mathrm{AlH}_{4}\right)_{2}, \mathrm{Ca}\left(\mathrm{AlH}_{4}\right)_{2}, \mathrm{Sr}\left(\mathrm{AlH}_{4}\right)_{2}$, and $\mathrm{Eu}\left(\mathrm{AlH}_{4}\right)_{2}$ [78-80].

Potassium alanate, $\mathrm{KAlH}_{4}\left(\rho_{\mathrm{m}}=5.7 \mathrm{wt} \% \mathrm{H}_{2}\right)$, has a less understood mechanism of decomposition as compared to $\mathrm{LiAlH}_{4}$ and $\mathrm{NaAlH}_{4}$. The formation of an intermediate has been observed experimentally and a crystal structure and composition of $\mathrm{K}_{3} \mathrm{AlH}_{6}$ has been suggested by density functional theory (DFT) calculations [37,81-83]. In contrast, experimental observations suggest a $\mathrm{K}_{\mathrm{y}} \mathrm{AlH}_{\mathrm{x}}$ compound with $1 \leq \mathrm{y} \leq 3$ and $4 \leq \mathrm{x} \leq 6$ [57]. The main advantage of $\mathrm{KAlH}_{4}$ over $\mathrm{LiAlH}_{4}$ and $\mathrm{NaAlH}_{4}$ is the reversible hydrogen sorption at low pressure ( $<10$ bar) and moderate temperature $\left(250-300{ }^{\circ} \mathrm{C}\right)$ without the need of additives [84].

In general the alkali metal alanates are less stable than the alkali metal borohydrides with decomposition temperatures of 60 to $300{ }^{\circ} \mathrm{C}$ as compared to $T>350^{\circ} \mathrm{C}$, respectively [2,67]. Hence, they may more easily become a practical hydrogen storage material, but generally with lower gravimetric hydrogen storage capacity.

\subsection{Metal Borohydrides}

In 2003, lithium borohydride, $\mathrm{LiBH}_{4}$, was proposed as a hydrogen storage material. Since then, a wide range of novel metal borohydrides has been discovered, due to the great coordination flexibility of the complex $\mathrm{BH}_{4}{ }^{-}$anion, which can act as a counter ion in the solid state, or coordinate to a metal via corner sharing $\left(\eta^{1}\right)$, edge sharing $\left(\eta^{2}\right)$, or face sharing $\left(\eta^{3}\right)[3,85]$. Metal borohydride structures appear to be related to structures of metal oxides, e.g., polymorphs of $\mathrm{Ca}\left(\mathrm{BH}_{4}\right)_{2}$ are isostructural to polymorphs of $\mathrm{TiO}_{2}$ [85].

\subsubsection{Monometallic Borohydrides}

Lithium is one of the lightest elements and $\mathrm{LiBH}_{4}$ has a high gravimetric and volumetric hydrogen density of $\rho_{\mathrm{m}}=18.4 \mathrm{wt} \% \mathrm{H}_{2}$ and $\rho_{\mathrm{V}}=122.5 \mathrm{~g} \mathrm{H}_{2} / \mathrm{L}$, respectively $[6,8,86,87]$. The structure of $\mathrm{LiBH}_{4}$ is orthorhombic (Pnma), $o$ - $\mathrm{LiBH}_{4}$, at room temperature whereas a first-order polymorphic transition into a hexagonal $\left(\mathrm{Pb}_{3} m c\right)$ structure, denoted $h$ - $\mathrm{LiBH}_{4}$, occurs at $T \sim 108^{\circ} \mathrm{C}[8,86,88]$. Both polymorphs contain relatively rigid, regular, and undistorted $\mathrm{BH}_{4}{ }^{-}$tetrahedra [89]. Furthermore, $\mathrm{LiBH}_{4}$ melts at $T \sim 275{ }^{\circ} \mathrm{C}$ and eventually decomposes at $T>350{ }^{\circ} \mathrm{C}$ into $\mathrm{LiH}$ and elemental $\mathrm{B}$ where the enthalpy change amounts to $\Delta H_{\mathrm{dec}}=74 \mathrm{~kJ} / \mathrm{mol} \mathrm{H}_{2}$ [25]. The other alkali metal borohydrides $M B_{4}$, $M=\mathrm{Na}, \mathrm{K}, \mathrm{Rb}$ and $\mathrm{Cs}$ have higher thermal stability and all crystallize in the Rock salt structure. Sodium borohydride is also stable in basic aqueous solutions, which has been used as a hydrogen storage media [90]. Alkali metal borohydrides are known to have the highest thermal stability, which hampers the possible application as hydrogen storage materials.

Only recently, the full series of alkaline earth metal borohydrides was completed with the discovery of $\mathrm{Ba}\left(\mathrm{BH}_{4}\right)_{2}, \mathrm{Sr}\left(\mathrm{BH}_{4}\right)_{2}$, and their chloride derivatives [91-93]. The alkaline earth metal borohydrides show decreasing degree of covalent and directional bonding in the series, $\mathrm{Mg}>\mathrm{Ca}>\mathrm{Sr}$ $>$ Ba. Magnesium borohydride is known in seven different polymorphs and, remarkably, one of these, $\gamma-\mathrm{Mg}\left(\mathrm{BH}_{4}\right)_{2}$, has permanent porosity and $30 \%$ of open space in the structure [94-103]. The heavier alkali earth metal borohydrides form three to four polymorphs [3].

A few transition metal borohydrides have also been described and those that are stable at room temperature have electron configurations $d^{0}, d^{5}$ or $d^{10}$ [2], i.e., containing the metal ions, $\mathrm{Sc}^{3+}, \mathrm{Y}^{3+}$, $\mathrm{Zr}^{4+}, \mathrm{Mn}^{2+}, \mathrm{Zn}^{2+}$ or $\mathrm{Cd}^{2+}$. A few less stable transition metal borohydrides are also described, e.g., $\mathrm{Ti}\left(\mathrm{BH}_{4}\right)_{3}\left(d^{1}\right)$ which sublimes at $T \sim 0{ }^{\circ} \mathrm{C}$, or $\mathrm{Fe}\left(\mathrm{BH}_{4}\right)_{2}$ which is stable in solution (at $T \sim-30^{\circ} \mathrm{C}$ ) and can be stabilized as $\left[\mathrm{Fe}\left(\mathrm{NH}_{3}\right)_{6}\right]\left(\mathrm{BH}_{4}\right)_{2}[104,105]$. 
Some monometallic borohydrides form molecular solids and sublime at low temperatures, e.g., $\mathrm{Al}\left(\mathrm{BH}_{4}\right)_{3}$ and $\mathrm{Zr}\left(\mathrm{BH}_{4}\right)_{4}$, where the latter is the most stable, $T_{\text {sub }}=29{ }^{\circ} \mathrm{C}$ and may be prepared by vapour deposition [106].

\subsubsection{Bimetallic Borohydrides}

Lithium potassium borohydride, $\mathrm{LiK}\left(\mathrm{BH}_{4}\right)_{2}$, was the first discovered bimetallic borohydride $[107,108]$. Later, a range of lithium, rubidium, and caesium borohydrides were described while also a solid solution of $\mathrm{Na}_{1-x} \mathrm{~K}_{x} \mathrm{BH}_{4}$ was discovered $[85,109]$. These compounds have structures similar to their parent monometallic borohydrides.

Bimetallic borohydrides, where the metals have increasing difference in Pauling electronegativity, have structures constructed of larger metal complexes with the most electronegative metal as the central ion and the less electronegative metal with dominantly ionic coordination. Thus, lithium scandium borohydride, $\mathrm{LiSc}\left(\mathrm{BH}_{4}\right)_{4}$, consists of $\left[\mathrm{Sc}\left(\mathrm{BH}_{4}\right)_{4}\right]^{-}$complexes and $\mathrm{Li}^{+}$ions. Additionally, a relationship between the Pauling electronegativity of the metal cation and the thermal stability of the metal borohydride has been established as higher electronegativity results in lower decomposition temperature, see Figure $2[2,110,111]$.

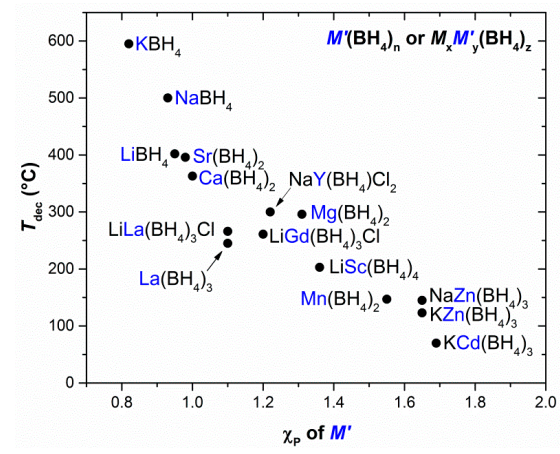

Figure 2. Thermal decomposition temperature of metal borohydrides as a function of the central metals electronegativity.

Sodium zinc borohydrides are known in two compositions, $\mathrm{NaZn}\left(\mathrm{BH}_{4}\right)_{3}$ and $\mathrm{NaZn}_{2}\left(\mathrm{BH}_{4}\right)_{5}$, which contain the complex ions $\left[\mathrm{Zn}\left(\mathrm{BH}_{4}\right)_{3}\right]^{-}$and $\left[\mathrm{Zn}_{2}\left(\mathrm{BH}_{4}\right)_{5}\right]^{-}$, respectively. The latter can also be described as two identical interpenetrated three-dimensional frameworks [112-114]. Strong and directional $\mathrm{Zn}-\mathrm{BH}_{4}$ bonding by edge sharing $\left(\mathrm{\eta}^{2}\right)$ is observed, which defines the structural architecture. The compound $\mathrm{LiCe}\left(\mathrm{BH}_{4}\right)_{3} \mathrm{Cl}$, has a very unique structure consisting of tetranuclear anionic clusters $\left[\mathrm{Ce}_{4} \mathrm{Cl}_{4}\left(\mathrm{BH}_{4}\right)_{12}\right]^{4-}$ with a distorted cubane $\mathrm{Ce}_{4} \mathrm{Cl}_{4}$ core $[3,115]$.

Perovskite structures have long been known for metal hydrides, e.g., $\mathrm{CsCaH}_{3}$ and $\mathrm{NaMgH}_{3}$ containing the anion $\mathrm{H}^{-}$[117-121]. However, only recently the first perovskite-type metal borohydride, $\mathrm{KMn}\left(\mathrm{BH}_{4}\right)_{3}$, was reported, though followed up by extensive research reporting multiple new perovskite-type metal borohydrides containing the complex anion $\mathrm{BH}_{4}{ }^{-}$, see also Figure 3 [116,122-124]. Structurally, the metal borohydride perovskites differ from regular oxide and halide $\mathrm{ABX}_{3}$ perovskites as their polymorphic transitions are not always intuitively towards higher symmetry with increasing temperature. $\mathrm{H}-\mathrm{H}$ repulsion between the $\mathrm{BH}_{4}{ }^{-}$ligands may in some cases result in lower symmetry.[123,125]. 


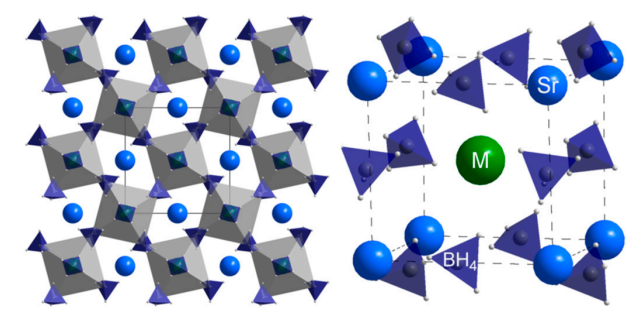

Figure 3. (Left) Structure of the perovskite-type $\mathrm{CsSr}\left(\mathrm{BH}_{4}\right)_{3}$ seen along the $c$-axis consisting of $\left[\mathrm{SrB}_{6}\right]$ octahedra and $\mathrm{Cs}^{+}$cations in interstitial positions; (Right) the similarity to a perovskite structure is highlighted with $\left[\mathrm{BH}_{4}{ }^{-}\right.$] groups on cell edge centres, Sr occupying the edge corners and the monovalent metal in the body centre [116].

\subsubsection{Trimetallic Borohydrides}

The first trimetallic borohydrides, $\mathrm{Li}_{3} \mathrm{MZn}_{5}\left(\mathrm{BH}_{4}\right)_{15}, M=\mathrm{Mg}$ and $\mathrm{Mn}$, presented in 2013 [126], were prepared by partial cation substitution in $\mathrm{LiZn}_{2}\left(\mathrm{BH}_{4}\right)_{5}$ using the chemical knowledge that the ions, $\mathrm{Li}^{+}, \mathrm{Mg}^{2+}, \mathrm{Mn}^{2+}$, and $\mathrm{Zn}^{2+}$ share some chemical properties and may substitute for each other in the solid state. The two compounds, $\mathrm{Li}_{3} \mathrm{MZn}_{5}\left(\mathrm{BH}_{4}\right)_{15}, M=\mathrm{Mg}$ and $\mathrm{Mn}$, are isostructural with cation disorder in the hexagonal $\left(\mathrm{PG}_{3} / \mathrm{mcm}\right)$ structure related to bimetallic $\mathrm{LiZn}_{2}\left(\mathrm{BH}_{4}\right)_{5}$ [126]. The five trimetallic compounds $A \mathrm{Li} M\left(\mathrm{BH}_{4}\right)_{4}(A=\mathrm{K}$ or $\mathrm{Rb} ; M=\mathrm{Mg}$ or $\mathrm{Mn})$ and $\mathrm{K}_{3} \mathrm{Li}_{2} \mathrm{Mg}_{2}\left(\mathrm{BH}_{4}\right)_{9}$ have negatively charged $\mathrm{Li}-\mathrm{Mg} / \mathrm{Mn}$ layered structures [127]. These trimetallic compounds have interesting structural relationships to aluminosilicates, e.g., $\mathrm{KAlSi}_{3} \mathrm{O}_{8}$ (feldspar), and may open new research directions, e.g., preparation of zeolite-like metal borohydrides. Similarly, zeolites contain three-dimensional negatively charged Al-Si-O networks [127]. Double perovskites $\mathrm{Li} A_{2} M\left(\mathrm{BH}_{4}\right)_{6}$ have been observed for large alkali metals $A=\mathrm{Rb}, \mathrm{Cs}$ and $M=\mathrm{Y}, \mathrm{Ce}, \mathrm{Gd}$ while the smaller alkali metal $A=\mathrm{K}$ stabilizes the garnet-type structure $\mathrm{Li}_{3} \mathrm{~K}_{3} M_{2}\left(\mathrm{BH}_{4}\right)_{12}$ for $M=\mathrm{La}$, Ce $[128,129]$.

\subsubsection{Metal Borohydrides Modified by Neutral Molecules}

Metal borohydrides have been modified with neutral molecules in order to improve hydrogen release and uptake properties [3]. Nitrogen-based molecules have attracted significant attention, e.g., ammonia, $\mathrm{NH}_{3}$, hydrazine, $\mathrm{N}_{2} \mathrm{H}_{4}$, and ammonia borane, $\mathrm{NH}_{3} \mathrm{BH}_{3}$, in order to introduce dihydrogen bonding via partly positively charged hydrogen atoms, e.g., $\mathrm{B}-\mathrm{H}^{\delta-} \ldots{ }^{+\delta} \mathrm{H}-\mathrm{N}$ in the solid state. Dihydrogen bonding is explored for tailoring thermal stability and decomposition. Trends in composition, structure, and properties for a range of new ammine metal borohydrides, $M\left(\mathrm{BH}_{4}\right)_{m} \cdot n \mathrm{NH}_{3}$, have been investigated recently. The interest in ammine metal borohydrides has increased tremendously during the past $\sim 5$ years [3,4]. The number of $\mathrm{BH}_{4}{ }^{-}$anions $(m)$ in the compounds is fixed and determined by the oxidation state of the metal, whereas the number of $\mathrm{NH}_{3}$ ligands $(n)$ may range from 1 to 8 , e.g., $\mathrm{Ca}\left(\mathrm{BH}_{4}\right)_{2} \cdot \mathrm{NH}_{3}$ and $\mathrm{Zr}\left(\mathrm{BH}_{4}\right)_{4} \cdot 8 \mathrm{NH}_{3}[130,131]$. In all cases the ammonia molecule, $\mathrm{NH}_{3}$, coordinates via the lone pair on $\mathrm{N}$ to the metal, and the $\mathrm{BH}_{4}{ }^{-}$anions coordinate in a more flexible way $\left(\eta^{0}-\eta^{3}\right)$. The most extensive series of crystalline ammine metal borohydride is formed by $\mathrm{Y}\left(\mathrm{BH}_{4}\right)_{3} \cdot n \mathrm{NH}_{3}(n=1,2,4,5,6$ and 7), which illustrates the great structural flexibility ranging from cation complexes $(n=6$ and 7), molecular neutral complexes ( $n=4$ and 5), one-dimensional chain like $(n=2)$, and two-dimensional layered structure $(n=1)$ [132].

Ammine metal borohydrides have been considered promising hydrogen storage materials, e.g., $\mathrm{Al}\left(\mathrm{BH}_{4}\right)_{3} \cdot 6 \mathrm{NH}_{3}, \mathrm{Li}_{2} \mathrm{Al}\left(\mathrm{BH}_{4}\right)_{5} \cdot 6 \mathrm{NH}_{3}$, and $\mathrm{Zn}\left(\mathrm{BH}_{4}\right)_{2} \cdot 2 \mathrm{NH}_{3}$ release 9 to $12 \mathrm{wt} \% \mathrm{H}_{2}$ in the temperature range 115 to $170{ }^{\circ} \mathrm{C}$ with traces of $\mathrm{NH}_{3}$ [133-135].

Interestingly, ammonia has a destabilizing effect for metal borohydrides with low metal electronegativity $\left(x_{p}<\sim 1.6\right)$ and a stabilizing effect for those with $x_{p}>\sim 1.6$. Thus the latter are often more thermally stable than their respective metal borohydride $[104,130]$. The stabilization may be due to complex formation and a shielding effect of the metal cation, which would otherwise be reduced to the metallic state, e.g., $\mathrm{Zn}\left(\mathrm{BH}_{4}\right)_{2} \cdot 4 \mathrm{NH}_{3}$ and $\mathrm{Zn}\left(\mathrm{BH}_{4}\right)_{2} \cdot 2 \mathrm{NH}_{3}$ [135]. 
Previously, a low $\mathrm{NH}_{3} / \mathrm{BH}_{4}{ }^{-}$ratio $(n / m \sim 1)$ and strong dihydrogen bonds were assumed to provide $\mathrm{H}_{2}$ rich (and $\mathrm{NH}_{3}$ poor) gas release during thermolysis. However, recent experimental results disagree with this hypothesis $[130,132,136]$. The composition of the released gas appears to depend on the thermal stability of the ammine metal borohydride, i.e., if it is similar to or higher than the thermal stability of the corresponding metal borohydride, then $\mathrm{H}_{2}$ is released. In contrast, mainly $\mathrm{NH}_{3}$ is released if the thermal stability of the ammine metal borohydride is significantly lower than the corresponding metal borohydride. For instance, the compounds, $M\left(\mathrm{BH}_{4}\right)_{m} \cdot n \mathrm{NH}_{3}, M=\mathrm{Al}, \mathrm{Zn}, \mathrm{Zr}$, and $\mathrm{V}$, release $\mathrm{H}_{2}$ (and maybe some $\mathrm{NH}_{3}$ ), e.g., $\mathrm{Al}\left(\mathrm{BH}_{4}\right)_{3} \cdot 6 \mathrm{NH}_{3}$ releases $\mathrm{H}_{2}$ and a small amount of $\mathrm{NH}_{3}$ at $T \sim 165^{\circ} \mathrm{C}[131,133,135,137]$.

Ammonia borane metal borohydride compounds have also been investigated, $M\left(\mathrm{BH}_{4}\right)_{m} \cdot n \mathrm{NH}_{3} \mathrm{BH}_{3}, M=\mathrm{Li}, \mathrm{Mg}, \mathrm{Ca}$, or $\mathrm{Al}$ [138-142]. They tend to separate during thermal treatment and $\mathrm{NH}_{3} \mathrm{BH}_{3}$ decomposes at $T>200{ }^{\circ} \mathrm{C}$ and the release of the toxic gasses is not suppressed, as observed for metal amidoboranes, $M\left(\mathrm{NH}_{2} \mathrm{BH}_{3}\right)_{m}$ [143]. An interesting amidoborane is the complex $\mathrm{Na}\left[\mathrm{Al}\left(\mathrm{NH}_{2} \mathrm{BH}_{3}\right)_{4}\right]$ which was found to reversibly absorb 1.7 mole of $\mathrm{H}_{2}$, although between two amorphous decomposition states [144]. Replacement of the $\mathrm{Na}^{+}$ion with a $\mathrm{K}^{+}$ion results in similar thermal decomposition temperatures. However, the reversibility seem to be disabled by this cation substitution [145].

\section{Complex Metal Hydrides for Electrochemical Applications}

Ni-metal hydride (Ni-MH) batteries have been used commercially in portable electrical devices since the early 1990's. The cathode consists of $\mathrm{Ni}(\mathrm{OH})_{2}$, while the anode is a $\mathrm{MH}$ and the electrolyte is an alkaline solution [146]. The overall reaction is:

$$
M H+\mathrm{NiOOH} \leftrightarrow M+\mathrm{Ni}(\mathrm{OH})_{2} \quad M: \text { Hydrogen storage alloy }
$$

The $\mathrm{LaNi}_{5}$-based $\mathrm{AB}_{5}$ type alloy was modified and commercially used as negative electrodes for $\mathrm{Ni}$-metal hydride batteries [147]. Even though the energy densities of these batteries are smaller than those of Li-ion batteries, they still play an important role in the market, especially for hybrid and fuel cell vehicles. Furthermore, several metal hydrides have been proposed as conversion type electrodes and others as electrolytes for complete solid state batteries. Different properties of metal hydrides have also been highlighted elsewhere [148].

\subsection{Metal Hydrides as Electrode Materials}

In 2008 use of metal hydrides as conversion type anodes in Li-ion batteries was proposed for the first time by Oumellal et al. [149]. In this concept, hydrides store lithium through the following general conversion reaction:

$$
\mathrm{MH}_{n}+n \mathrm{Li} \rightarrow n \mathrm{LiH}+\mathrm{M} \quad \text { M: Metal or intermetallic hydride }
$$

The first investigation in 2008 focused on $\mathrm{MgH}_{2}$ as the anode material, but the study also showed successful conversion reactions for $\mathrm{TiH}_{2}, \mathrm{NaH}, \mathrm{LaNi}_{4.25} \mathrm{Mn}_{0.75} \mathrm{H}_{5}$ and $\mathrm{Mg}_{2} \mathrm{NiH}_{3.7}$. The high theoretical capacities of the hydrides (e.g., $2038 \mathrm{mAh} / \mathrm{g}$ for $\mathrm{MgH}_{2}$, i.e., more than five times that of graphite) naturally caused significant interest for this new class of anodes. Furthermore, the investigation revealed that magnesium hydride exhibits smaller cell polarization ( $\Delta V$ between charge and discharge) than any of the other previously investigated conversion type electrodes (e.g., electrodes based on nitrides, sulfides and oxides) [149]. Unfortunately, hydride materials show limitations in their initial capacity (relative to the theoretical values) and large capacity loss upon cycling, which is subscribed to poor electronic conductivity and the large volume change occurring in the electrode during cycling, which may lead to poor contact. The capacity of $\mathrm{MgH}_{2}$ can be improved by limiting the amount of inserted lithium [149], through careful formulation (e.g., choice of binder) and choice of electrolyte. Hereby, a capacity retention for $\mathrm{MgH}_{2}$ of $542 \mathrm{mAh} / \mathrm{g}$ over 40 cycles has been achieved [150]. 
Subsequently, several studies have investigated Li-ion storage in $\mathrm{MgH}_{2}$ [151-158], $\mathrm{TiH}_{2}$ [159,160], $\mathrm{AlH}_{3}$ [151,161], M-LiH (M = Mg, Ti) [162] and $\mathrm{TiH}_{2}-\mathrm{MgH}_{2}$ [163] composites as well as a series of Mg-based complex hydrides such as $\mathrm{Mg}_{2} \mathrm{FeH}_{6}, \mathrm{Mg}_{2} \mathrm{CoH}_{5}$ and $\mathrm{Mg}_{2} \mathrm{NiH}_{4}$ [164]. For detailed descriptions of these results we refer to other reviews $[165,166]$.

Li-ion storage through conversion reactions in lithium and sodium alanate, $\mathrm{LiAlH}_{4}$ and $\mathrm{NaAlH}_{4}$, were investigated for the first time in 2015 [161,167,168]. The theoretical capacity for these materials is $\sim 2000 \mathrm{mAh} / \mathrm{g}$ when considering reaction with $3 \mathrm{Li}$ equivalents and full reduction to $\mathrm{LiH}$ and metallic aluminium. Silvestri et al. [168] obtained an initial discharge capacity of $1180 \mathrm{mAh} / \mathrm{g}$ for $\mathrm{LiAlH}_{4}$, corresponding to storage of $1.67 \mathrm{Li}$ equivalent, at discharge potentials dominated by extended plateaus at $0.78,0.26$ and $0.16 \mathrm{~V}$ versus $\mathrm{Li}$. The conversion reaction has been shown by powder $\mathrm{X}$-ray diffraction to occur through the following steps:

$$
\begin{gathered}
2 \mathrm{LiAlH}_{4}+3 \mathrm{Li}^{+}+3 \mathrm{e}^{-} \rightarrow \mathrm{Li}_{3} \mathrm{AlH}_{6}+\mathrm{Al}+2 \mathrm{LiH} \\
\mathrm{Li}_{3} \mathrm{AlH}_{6}+3 \mathrm{Li}^{+}+3 \mathrm{e}^{-} \rightarrow \mathrm{Al}+6 \mathrm{LiH}
\end{gathered}
$$

The formation of $\mathrm{Al}$ results in formation of the $\mathrm{LiAl}$ alloy according to the following reaction, which is predicted to occur below $0.29 \mathrm{~V}$ [168].

$$
\mathrm{Li}^{+}+\mathrm{e}^{-}+\mathrm{Al} \rightarrow \mathrm{LiAl}
$$

The reversible capacity in the first charge is less than $1 / 3$ of the capacity in the first discharge with the alloying/de-alloying reaction being responsible for the majority of the reversible capacity.

For $\mathrm{NaAlH}_{4}$ anodes initial capacities of $1700-1800 \mathrm{mAh} / \mathrm{g}$ can be achieved according to Reale et al. [167] with the majority of the Li storage reaction taking place at potentials $<0.45 \mathrm{~V}$. High energy ball milling with conductive carbon (Super P) for $15 \mathrm{~h}$ improves the reversible capacity in the first cycle from less than $30 \%$ to almost $70 \%$. The discharge mechanism is still not completely agreed upon. In general, multiple reaction steps are reported and the bi-alkali hexa-alanate, $\mathrm{LiNa}_{2} \mathrm{AlH}_{6}$ is a common intermediate [161,167].

$$
\begin{gathered}
\mathrm{NaAlH}_{4}+3 / 2 \mathrm{Li}^{+}+3 / 2 \mathrm{e}^{-} \rightarrow 1 / 2 \mathrm{LiNa}_{2} \mathrm{AlH}_{6}+1 / 2 \mathrm{Al}+\mathrm{LiH} \\
\mathrm{LiNa}_{2} \mathrm{AlH}_{6}+5 \mathrm{Li}^{+}+5 \mathrm{e}^{-} \rightarrow 2 \mathrm{Na}+\mathrm{Al}+6 \mathrm{LiH}
\end{gathered}
$$

However, Reale et al. [167] also observed formation of the sodium hexa-alanate, $\mathrm{Na}_{3} \mathrm{AlH}_{6}$ (Equation (12)), which is suggested to be a competitive process affected by kinetic limitations. Formation of $\mathrm{Na}_{3} \mathrm{AlH}_{6}$ during discharge was also confirmed in a separate study through ${ }^{23} \mathrm{Na}$ and ${ }^{27} \mathrm{Al}$ solid state NMR [169].

$$
3 \mathrm{NaAlH}_{4}+6 \mathrm{Li}+6 \mathrm{e}^{-} \rightarrow \mathrm{Na}_{3} \mathrm{AlH}_{6}+6 \mathrm{LiH}+2 \mathrm{Al}
$$

Reale et al. also used the hexa-alanates $\mathrm{Na}_{3} \mathrm{AlH}_{6}$ and $\mathrm{LiNa}_{2} \mathrm{AlH}_{6}$ directly as anodes, which were found to behave similarly to the alanates.

Recently, attempts were made to improve the reversibility of $\mathrm{NaAlH}_{4}$ by nanoconfinement in mesoporous carbon scaffolds [170,171]. Nanoconfinement seems to alter the conversion mechanism by enhancing the conversion from $\mathrm{NaAlH}_{4}$ to $\mathrm{Na}_{3} \mathrm{AlH}_{6}$. Also it appears to increase the capacity retention of the system, however the results suggests that the majority of the long term capacity stems from the carbon scaffolds [171].

Metal borohydrides have very high theoretical capacities, e.g., $4992 \mathrm{mAh} / \mathrm{g}$ for $\mathrm{LiBH}_{4}$ and thus have great potential as future anode materials. However, only a few studies of borohydride-based anodes exists $[172,173]$. Theoretical calculations predict that Li-conversion reactions are thermodynamically feasible for a long list of metal borohydrides both through a one-step mechanism with direct formation of the metal, elemental boron and lithium hydride, or through 
a two-step reaction with formation of a metal hydride as an intermediate. In the same investigation, five mono-metallic borohydrides, $M\left(\mathrm{BH}_{4}\right)_{n}(\mathrm{M}=\mathrm{Li}, \mathrm{Na}, \mathrm{K}, \mathrm{Mg}$ and $\mathrm{Ca})$ were tested as anodes in Li-ion batteries. $\mathrm{Ca}\left(\mathrm{BH}_{4}\right)_{2}$ appears to be electrochemically inactive, and for $\mathrm{LiBH}_{4}$ and $\mathrm{KBH}_{4}$ capacities below $75 \mathrm{mAh} / \mathrm{g}$ were achieved in the first discharge. $\mathrm{Mg}\left(\mathrm{BH}_{4}\right)_{2}$ and $\mathrm{NaBH}_{4}$ exhibited initial capacities of $\sim 540$ and $250 \mathrm{mAh} / \mathrm{g}$, which is well below their theoretical capacities of 3971 and $2834 \mathrm{mAh} / \mathrm{g}$, respectively. Furthermore, the reversible capacity in the second discharge is less than $50 \%$. Thus, it appears that metal borohydride based systems require further improvements in order to yield results comparable to those obtained for the metal alanates.

\subsection{Complex Metal Hydrides as Electrolytes}

Metal borohydrides have recently been employed as a new class of solid-state electrolytes for batteries [174,175] and the main advantages of light-weight CMHs are: (i) low material density compared to similar oxides and chalcogenides (can be two to three times lower); (ii) thinner solid state electrolytes, hence (i) and (ii) provide higher battery energy density; (iii) safer batteries because flammable organic ionic liquids and polymeric electrolytes are avoided; and (iv) easier assembly of all-solid-state batteries [176].

Research on metal borohydrides and derivatives, oxides and chalcogenides as solid state electrolytes have been mainly focused on monovalent alkali metals, $\mathrm{Li}^{+}$and $\mathrm{Na}^{+}$. Indeed, multivalent cations, e.g., $\mathrm{Mg}^{2+}, \mathrm{Ca}^{2+}$, and $\mathrm{Al}^{3+}$, may further increase the energy density of solid state batteries. However, development of fast ion conductors for these cations is challenging due to much larger charge density as compared to mono-valent cations. Therefore, very large, low charge density anions, such as closo-boranes, $\mathrm{B}_{12} \mathrm{H}_{12}{ }^{2-}$, or closo-carboranes, $\mathrm{CB}_{11} \mathrm{H}_{12}{ }^{-}$, may prove useful for design of new electrolytes.

The high-temperature polymorph $h$ - $\mathrm{LiBH}_{4}$ was among the first metal hydrides to be discovered as fast ion conductors with $\mathrm{Li}^{+}$conductivity of the order of $10^{-3} \mathrm{~S} \mathrm{~cm}^{-1}$ at $T>115^{\circ} \mathrm{C}$ [177]. Attempts to stabilize the high-temperature polymorph at room temperature were successful by halide-substitution of the borohydride group, i.e., $h$ - $\mathrm{Li}\left(\mathrm{BH}_{4}\right)_{1-\mathrm{x}} \mathrm{I}_{\mathrm{x}}$ [178-180]. Reversible $\mathrm{Mg}$ stripping/plating has been demonstrated using $\mathrm{Mg}\left(\mathrm{BH}_{4}\right)_{2}$ as an electrolyte in THF and dimethoxyethane solutions [181]. However, the conductivity of solid state $\mathrm{Mg}\left(\mathrm{BH}_{4}\right)_{2}$ is very low $\left(<10^{-12} \mathrm{~S} \mathrm{~cm}^{-1}\right.$ at $\left.30^{\circ} \mathrm{C}\right)$ [182] but may be enhanced in double anion compounds, e.g., $\mathrm{Mg}\left(\mathrm{BH}_{4}\right)\left(\mathrm{NH}_{2}\right)$ has a $\mathrm{Mg}^{2+}$ conductivity of $1 \times 10^{-6} \mathrm{~S} \mathrm{~cm}^{-1}$ at $\mathrm{T}=150^{\circ} \mathrm{C}$ [183]. Recently, the addition of ethylene diamine, $\mathrm{NH}_{2}\left(\mathrm{CH}_{2}\right)_{2} \mathrm{NH}_{2}$ (en), to $\mathrm{Mg}\left(\mathrm{BH}_{4}\right)_{2}$ resulted in the formation of cis- $\mathrm{Mg}(e n)\left(\mathrm{BH}_{4}\right)_{2}$ which shows ion conductivity between $5 \times 10^{-8}$ and $6 \times 10^{-5} \mathrm{~S} \mathrm{~cm}^{-1}$ in the temperature range 30 to $70{ }^{\circ} \mathrm{C}$, respectively [182]. So far, the most promising compounds are $\mathrm{Na}_{2} \mathrm{~B}_{10} \mathrm{H}_{10}$ and $\mathrm{Na}_{2} \mathrm{~B}_{12} \mathrm{H}_{12}$, which show superionic conductivity in the high-temperature polymorphs (phase transition at 87 and $207^{\circ} \mathrm{C}$, respectively) with $\mathrm{Na}$ ion conductivity of $\sim 0.01$ and $0.1 \mathrm{~S} \mathrm{~cm}^{-1}$, respectively [184,185].

Intermolecular anion substitution in metal borohydrides has been explored as a valuable technique for tailoring physical and chemical properties [3]. The heavier halides have provided a wide range of metal borohydride halides with either fully ordered, e.g., $\mathrm{KZn}\left(\mathrm{BH}_{4}\right)_{2} \mathrm{Cl}$ or $\mathrm{Sr}\left(\mathrm{BH}_{4}\right) \mathrm{Cl}[92,186]$, partly ordered, e.g., $\mathrm{NaY}\left(\mathrm{BH}_{4}\right)_{2-x} \mathrm{Cl}_{2+x}[187,188]$, or disordered structures, e.g., $\mathrm{K}_{2} \mathrm{Zn}\left(\mathrm{BH}_{4}\right)_{x} \mathrm{Cl}_{4-x}[189]$. The smaller fluoride ion can substitute for the hydride ion, i.e., intramolecular anion substitution, $\mathrm{F}^{-} \rightarrow \mathrm{H}^{-}$, in the $\mathrm{BH}_{4}{ }^{-}$complex and the composite $\mathrm{NaBH}_{4}-\mathrm{NaBF}_{4}$ provided the first fluorine-substituted borohydride, $\mathrm{NaBH}_{2.1} \mathrm{~F}_{1.9}$, observed in the temperature range of $200-215^{\circ} \mathrm{C}[190,191]$.

Recently, a new class of $\mathrm{Li}$ ion conductors was discovered, $\mathrm{LiRe}\left(\mathrm{BH}_{4}\right)_{3} \mathrm{Cl}, \mathrm{Re}=\mathrm{La}, \mathrm{Ce}, \mathrm{Pr}, \mathrm{Nd}$, $\mathrm{Sm}, \mathrm{Gd}$, with an interesting new structure type $[115,192-194]$. The structure reveals disordered $\mathrm{Li}^{+}$ ions that occupy only $2 / 3$ of the $12 d$ Wyckoff sites, but a fully ordered anion lattice. The $\mathrm{Li}^{+}$ion conductivity for $\mathrm{LiCe}\left(\mathrm{BH}_{4}\right)_{3} \mathrm{Cl}$ was measured to be $1.03 \times 10^{-4} \mathrm{Scm}^{-1}$, at $20^{\circ} \mathrm{C}$ [115]. Additionally, solid-state ${ }^{1} \mathrm{H},{ }^{11} \mathrm{~B}$, and ${ }^{7} \mathrm{Li} \mathrm{NMR}$ measurements of spin-lattice relaxation rates of $\mathrm{LiLa}\left(\mathrm{BH}_{4}\right)_{3} \mathrm{Cl}$ reveal two types of dynamics on the same frequency scale, i.e., Li-ion diffusion and reorientational motion of $\mathrm{BH}_{4}{ }^{-}$groups. Therefore the Li-ion diffusion and the dynamics of $\mathrm{BH}_{4}{ }^{-}$complexes appear to be 
correlated, which suggests a paddle wheel mechanism is responsible for fast ionic mobility $[195,196]$. Anion substitution in this class of materials is also possible, i.e., $\mathrm{LiLa}\left(\mathrm{BH}_{4}\right)_{3} \mathrm{X}, \mathrm{X}=\mathrm{Cl}, \mathrm{Br}$, I, which may open new possibilities for improvement of ion conductivity by tailoring the structural aperture for cation diffusion in the solid materials $[197,198]$.

New types of double anion hydride-oxides, i.e., containing $\mathrm{BH}_{4}{ }^{-}$and $\mathrm{BO}_{3}{ }^{3-}$, have also been discovered recently $[199,200]$, which may suggest formation of new types of hydrides containing, also $\mathrm{SO}_{4}{ }^{2-}, \mathrm{PO}_{4}{ }^{3-}$, or $\mathrm{PS}_{4}{ }^{3-}$, which may be compatible with known electrode materials.

A new class of silver closo-boranes was discovered recently, $\mathrm{Ag}_{2} \mathrm{~B}_{12} \mathrm{H}_{12}$ and $\mathrm{Ag}_{2} \mathrm{~B}_{10} \mathrm{H}_{10}$, with high ion conductivities. Anion substitution with iodine stabilizes a high temperature polymorph with ion conductivity up to $3.2 \mathrm{mS} \mathrm{cm}^{-1}$ at room temperature [201]. Partly or fully halogenated closo-boranes may in future be useful to create new materials with higher conductivities [202,203].

Substitution of a boron atom with a carbon atom in closo-boranes leads to the formation of closo-carboranes, e.g., $\mathrm{CB}_{11} \mathrm{H}_{12}{ }^{-}$with even lower charge density. Particularly, $\mathrm{LiCB}_{11} \mathrm{H}_{12}$, and $\mathrm{NaCB}_{11} \mathrm{H}_{12}$ have lower polymorphic transition temperatures $\left(127\right.$ and $107^{\circ} \mathrm{C}$, respectively) compared to the analogues $\mathrm{Li}_{2} \mathrm{~B}_{12} \mathrm{H}_{12}$ and $\mathrm{Na}_{2} \mathrm{~B}_{12} \mathrm{H}_{12}$ ( 342 and $256{ }^{\circ} \mathrm{C}$, respectively) while showing some of the most promising $\mathrm{Li}$ and $\mathrm{Na}$ ion conductivities of $>0.1 \mathrm{~S} \mathrm{~cm}^{-1}$ yet observed [204].

\section{Complex Metal Hydrides for Thermal Energy Storage}

There are thousands of metals, metal alloys and compounds that can reversibly react with gaseous hydrogen [205] at temperatures as low as $-100{ }^{\circ} \mathrm{C}\left(\mathrm{TiCr}_{1.9} \mathrm{H}_{3.5}\right.$ [206]) and as high as $1100{ }^{\circ} \mathrm{C}$ $\left(\mathrm{LaH}_{\mathrm{x}}\right.$ [207]). The absorption of hydrogen is an exothermic process that releases heat while the desorption of hydrogen is an endothermic process that absorbs heat and the direction of the reaction can be controlled by changing either the hydride temperature or hydrogen pressure. This property of metal hydrides means that they can be exploited for a wide range of closed-loop energy storage and energy transformation applications including as; $\mathrm{H}_{2}$ compressors; hydride heat engines, actuators and temperature sensors; thermochemical heat storage; heat pumping and thermally driven refrigeration. In fact, many of the relevant engineering principles were developed and proven during the 1970s and 1980s based on the high-cost, low capacity intermetallic hydrides known at the time. Extensive reviews on the progress of metal hydrides for these applications have been published [208-211]. However, a consistent road block to the commercialisation of metal hydrides for these applications has been the relatively low $\mathrm{H}_{2}$ capacity and high cost of traditional intermetallic hydrides based on transition metals [210].

With the commercialization of concentrating solar power plants (CSPs) incorporating molten nitrate salts heat storage and, in conjunction with the U.S. Department of Energy SunShot Initiative to drive down the cost of solar electricity [212], there has been a renewed focus on the potential of low-cost, high-temperature metal hydrides to be the second generation of CSP heat storage materials that can operate at temperatures above $600{ }^{\circ} \mathrm{C}$ [213-217]. This is because the thermochemical heat storage capacity of metal hydrides can exceed the sensible heat storage capacity of molten salts by a factor of $>10$ [216]. In fact, the theoretical thermochemical heat storage capacity of some metal hydrides, such as $\mathrm{LiH}$ and $\mathrm{CaH}_{2}$, are only exceeded by methane reforming reactions [214,218]. Specific details about the energy cycle for using metal hydrides as high temperature heat storage materials for CSP can be found elsewhere [67,214,219-222]. Besides the intermetallic hydrides first considered for heat storage in the 1970s and 1980s, most of the research on metal hydrides for high temperature heat storage $\left(T>400{ }^{\circ} \mathrm{C}\right)$ has focused on a few particular sub-sets. These include: simple binary/ternary hydrides and their partially fluorinated analogues [216], such as $\mathrm{MgH}_{2}$ [223-227], $\mathrm{NaH} / \mathrm{NaH}_{1-\mathrm{x}} \mathrm{F}_{\mathrm{x}}$ [215,228], $\mathrm{NaMgH}_{3} / \mathrm{NaMgH}_{2} \mathrm{~F}$ [229,230], and $\mathrm{TiH}_{\mathrm{x}}$ [213]; destabilized binary hydrides, such as $\mathrm{LiH}-\mathrm{Al}$ [231], $x \mathrm{LiH}-\mathrm{Si}$ [232,233], and $\mathrm{CaH}_{2}-\mathrm{Al}$ [234] and; complex transition metal hydrides, such as $\mathrm{Mg}_{2} \mathrm{NiH}_{4}[235,236], \mathrm{Mg}_{2} \mathrm{FeH}_{6}$ [236,237], $\mathrm{Mg}_{2} \mathrm{CoH}_{5}$, and $\mathrm{Mg}_{6} \mathrm{CoH}_{11}$ [236]. The high thermodynamic stability in conjunction with their high hydrogen capacity make CMHs intriguing candidates as thermochemical heat storage materials for CSP and for industrial waste heat recovery 
and utilization. Despite this, $\mathrm{CMHs}$ have rarely been considered for heat storage applications with examples in the literature limited to: the $\mathrm{Li}_{2} \mathrm{NH} / \mathrm{Li}_{4} \mathrm{NH}$ system [238]; $\mathrm{Na}_{3} \mathrm{AlH}_{6}, \mathrm{Na}_{2} \mathrm{LiAlH}_{6}$ and $\mathrm{K}_{2} \mathrm{NaAlH}_{6}$ [215] and; $6 \mathrm{LiBH}_{4}+\mathrm{CaH}_{2}$ [239].

For this review, we have used the thermodynamic data reported in the literature for the $\mathrm{H}_{2}$ absorption/desorption from CMHs to calculate properties relevant for heat storage, Figure $4 \mathrm{a}, \mathrm{b}$ and Table 2. Figure 4a shows the theoretical gravimetric and volumetric heat storage capacities of $15 \mathrm{CMH}$ systems compared to other well-known: (1) thermochemical heat storage materials (TCMs) based on metal hydrides, carbonates, hydroxides and oxides; (2) phase change materials (PCMs) and; (3) sensible heat storage materials (SHMs). Another important factor in determining the suitability of a metal hydride for a particular application is the $\mathrm{H}_{2}$ equilibrium pressure which increases exponentially with temperature. Figure $4 \mathrm{~b}$ shows the temperature dependent $\mathrm{H}_{2}$ equilibrium pressure for the $\mathrm{CMH}$ systems, with $\mathrm{NaH}, \mathrm{MgH}_{2}, \mathrm{Mg}_{2} \mathrm{NiH}_{4}, \mathrm{Mg}_{2} \mathrm{FeH}_{6}$ and $\mathrm{TiH}_{1.0-1.6} \mathrm{H}$ included as comparisons. $\mathrm{The}_{2}$ equilibrium pressures have been plotted up to a value of 150 bar except for where thermodynamic data is not available, i.e., above the melting point of $\mathrm{NaBH}_{4}$.

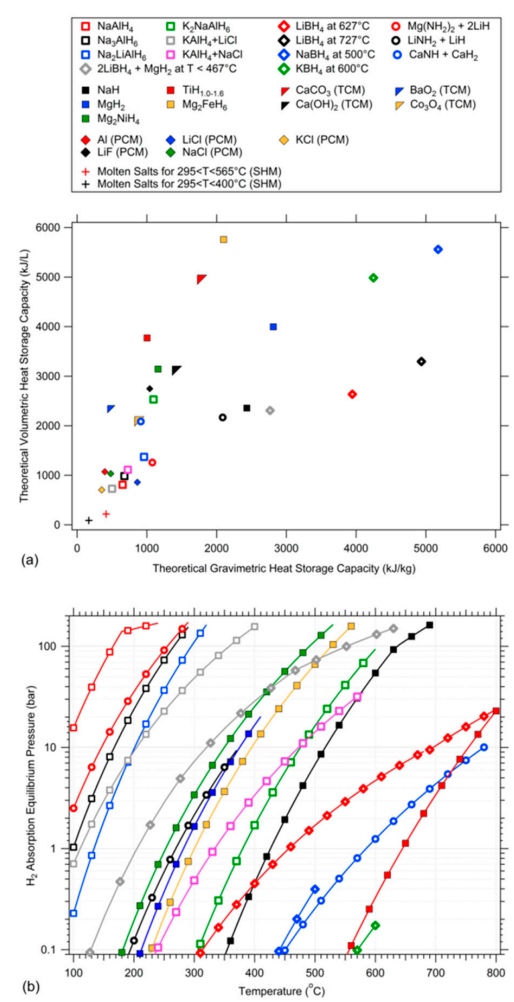

Figure 4. (a) Theoretical volumetric heat storage capacities versus gravimetric heat storage capacities for complex hydrides with a number of other heat storage materials included for comparison; (b) Hydrogen absorption equilibrium pressures of complex hydrides versus temperature. Data for some well-known heat storage metal hydrides are included as a comparison. Open symbols refer to data for complex hydrides. TCM = thermochemical heat storage material, $\mathrm{PCM}=$ phase change heat storage material, $\mathrm{SHM}=$ sensible heat storage material.

Figure 4a shows that the theoretical gravimetric and volumetric heat storage capacities of $\mathrm{LiBH}_{4}$ (4936 kJ $/ \mathrm{kg}$ and $3296 \mathrm{~kJ} / \mathrm{L}$ at $727^{\circ} \mathrm{C}$ [240]), $\mathrm{NaBH}_{4}\left(5176 \mathrm{~kJ} / \mathrm{kg}\right.$ and $5559 \mathrm{~kJ} / \mathrm{L}$ at $507.5^{\circ} \mathrm{C}$ [241]) and $\mathrm{KBH}_{4}\left(4248 \mathrm{~kJ} / \mathrm{kg}\right.$ and $4986 \mathrm{~kJ} / \mathrm{L}$ at $615.5^{\circ} \mathrm{C}$ [241]) are some of the highest known for a gas-solid thermochemical reaction. Only $\mathrm{LiH}\left(8389 \mathrm{~kJ} / \mathrm{kg}\right.$ and $6543 \mathrm{~kJ} / \mathrm{L}$ at $938^{\circ} \mathrm{C}$ [241]) and $\mathrm{CaH}_{2}(3857 \mathrm{~kJ} / \mathrm{kg}$ and $7374 \mathrm{~kJ} / \mathrm{L}$ at $1018{ }^{\circ} \mathrm{C}$ [241]) have theoretical gravimetric and/or volumetric heat storage capacities that are higher. However, the theoretical operating temperatures for $\mathrm{LiBH}_{4}, \mathrm{NaBH}_{4}$ and $\mathrm{KBH}_{4}$ are well within the target window of $600-800{ }^{\circ} \mathrm{C}$ for next generation CSP [212], whereas $\mathrm{LiH}$ and $\mathrm{CaH}_{2}$ 


\section{Complex Metal Hydrides and Fuel Cell Applications}

An emerging research direction is that of $\mathrm{CMHs}_{\mathrm{s}} \mathrm{H}_{2}$ storage materials for stationary fuel cells (FCs) for clean power generation in seasonal storage, remote area and off-grid applications [261-264]. Unlike the closed-loop applications discussed in Section 4, this application utilizes an electrolyser to produce $\mathrm{H}_{2}$, which is stored (e.g., in a metal hydride) until the consumption of hydrogen by the fuel cell is required for electricity production. Interest in the use of classic intermetallic hydrides for this role began in the 1990s [261,262] and an in-depth review of the principles and progress on the use of metal hydrides in fuel cell applications has recently been published [264]. Some of the advantages of energy storage based on a photo voltaic (PV)-electrolyser- $\mathrm{H}_{2}$ storage-fuel cell configuration over a PV-Li ion battery system include:

Self-discharge: All batteries steadily lose charge over time and the self-discharge rate of Li-ion is highly dependent on temperature and the state-of-charge (SOC). The higher the temperature/SOC, the higher self-discharge rate [265]. The self-discharge rate of Li-ion batteries is usually 3-5\% a month [265]. However, ageing of the battery may influence the self-discharge rate significantly [266]. In comparison, metal hydrides do not undergo "self-discharge" and can store their "charge" indefinitely.

Safety: Li-ion batteries suffer from lithium dendrite formation which may lead to short-circuit of the battery. Additionally, the organic electrolyte is hazardous in the presence of an oxidizing agent, which may result in runaway reactions and the battery catching fire or exploding [267]. The classic intermetallic hydrides first studied at near-ambient temperatures in combination with FCs have intrinsic safety due to their modest $\mathrm{H}_{2}$ pressures and operating temperatures combined with the endothermic nature of the $\mathrm{H}_{2}$ release process [264]. A more complicated scenario is presented by $\mathrm{CMHs}$ due to the fact that they are, in general, strong reducing agents, and many have the potential to be flammable or pyrophoric upon contact with air or water. However, in practical applications $\mathrm{CMHs}$ are typically used in the form of dense compacts and research on these has shown that they only undergo a mild temperature increase on exposure to air, and that direct immersion in water results in a mild temperature increase combined with slow release of $\mathrm{H}_{2}[268,269]$. A comprehensive determination of the safety of $\mathrm{CMHs}$ would require performing reactivity testing at their practical operating temperatures.

Deep discharge: Unlike rechargeable batteries [270], metal hydride systems do not, in general, suffer capacity loss from being fully discharged [263].

Longevity: A battery's cycle life is defined as the number of cycles until the capacity reaches $80 \%$ of its initial reversible value [271]. Commonly, Li-ion batteries have a cycle life between 1000 and 4500 cycles, i.e., a lifetime between 7 and 20 years [272]. Li-ion batteries with a 95\% retention after 30,000 cycles have been discovered, however, at the expense of energy density [273], which is a severe drawback. In comparison, $\mathrm{LaNi}_{5}$ showed no capacity loss over 3300 cycles when using a $\mathrm{H}_{2}$ purity above $99.9999 \%$ [274]. Furthermore, $\mathrm{TiFe}_{0.8} \mathrm{Ni}_{0.2}$ showed only a $16 \%$ capacity loss after 65,000 cycles: equivalent to a $\sim 178$ year product lifetime based on a daily cycling regime [275]. The biggest issue so far for the CMHs is the reversibility and cyclic stability and much less long term cycling has been performed.

System size: As the energy density of CMHs is much higher than for Li-ion batteries, the system size of a stationary energy storage system will be much denser [263]. Additionally, the mass of an extensive Li-ion battery capable of storing large amounts of energy is considerable [276].

An additional benefit of thermally integrating CMHs with moderate- and high-temperature FCs is that, by consuming a significant fraction of the waste heat generated, the CMHs could actually improve the thermal control of high-temperature FC stacks [264].

One of the original driving forces for reducing the operating temperature of high capacity CMHs was that they could be used in mobile applications/passenger vehicles, where the waste heat $\left(\sim 80^{\circ} \mathrm{C}\right)$ of Low Temperature Proton Exchange Membrane Fuel Cells (LT-PEMFCs) could 
be used to release $\mathrm{H}_{2}$ for FC consumption. However, $\mathrm{H}_{2}$ storage in complex hydrides with high thermodynamic stability is less of an issue for stationary applications as a number of different types of fuel cells are available that operate in different temperature ranges (AFC $=$ Alkaline Fuel Cell, HT-PEMFC $=$ High-Temperature Proton Exchange Membrane Fuel Cell, PAFC $=$ Phosphoric Acid Fuel Cell, MCFC = Molten Carbonate Fuel Cell, SOFC = Solid Oxide Fuel Cell). Consequently, using complex hydride systems such as $\mathrm{NaAlH}_{4}$ [277-282] and $\mathrm{Mg}\left(\mathrm{NH}_{2}\right)_{2}+2 \mathrm{LiH}$ [283] in conjunction with HT-PEMFCs is now being investigated. The integration of SOFCs with $\mathrm{MgH}_{2}$ [284-288], a metal hydride that historically suffered from high thermodynamic stability and poor kinetics, highlights the potential of CMHs for this application.

The different types of FCs are characterized by different operating temperatures as well as different efficiencies. The efficiency of the FC determines the amount of waste heat generated, $Q_{\text {loss, }}$ which can be used to release $\mathrm{H}_{2}$ from the metal hydride provided it exceeds the enthalpy of desorption, $\Delta H_{\text {des }}$. The potential for thermal integration of a CMH with a particular type of FC can be assessed by considering their respective operating temperatures and the amount of waste heat available in comparison to that required to release $\mathrm{H}_{2}$ from the $\mathrm{CMH}$. Figure 5 presents this comparison for the $\mathrm{CMH}$ systems and $\mathrm{NaH}, \mathrm{MgH}_{2}, \mathrm{Mg}_{2} \mathrm{NiH}_{4}, \mathrm{Mg}_{2} \mathrm{FeH}_{6}$ and $\mathrm{TiH}_{1.0-1.6}$. It also includes the general range that applies to intermetallic hydrides, as a comparison, since most fuel cell integration research has been performed with these types of hydrides. Not all metal hydrides are suitable as $\mathrm{H}_{2}$ storage materials when paired with FCs. As an example, $\mathrm{TiH}_{1.0-1.6}$ would not be appropriate for use with any of the fuel cells, regardless of type, as the thermal energy required for $\mathrm{H}_{2}$ release, exceeds the waste heat available from the fuel cell.

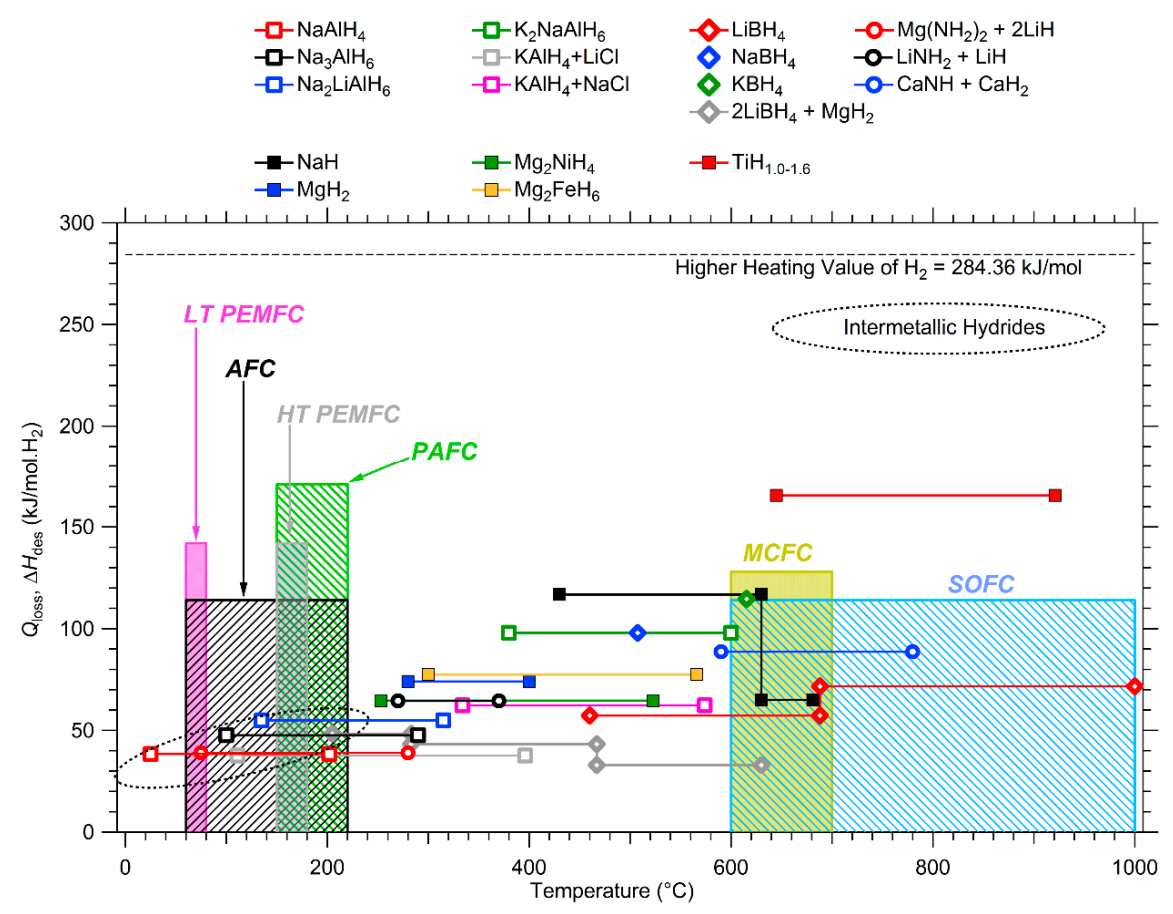

Figure 5. Potential of various metal hydrides, based on their $\mathrm{H}_{2}$ enthalpy of desorption $\left(\Delta H_{\mathrm{des}}\right)$, and the associated heat loss $\left(Q_{\text {loss }}\right)$ of different types of fuel cells. The operating temperature range of the metal hydrides corresponds to $\mathrm{H}_{2}$ absorption equilibrium pressures of between 1 and 150 bar unless otherwise noted in Table 2. The step changes that occur for the $\mathrm{NaH}$ and $\mathrm{LiBH}_{4}$ curves are a result of a phase change for either one of the reactants or products. This figure is based on that from reference [264].

The choice of $\mathrm{CMH}$ for $\mathrm{H}_{2}$ storage when paired with a particular $\mathrm{FC}$ will be dependent on the application under consideration. Some of the potential deciding factors include: $\mathrm{CMH}$ cost; cost and 
complexity of thermal integration between the $\mathrm{CMH}$ and $\mathrm{FC} ; \mathrm{CMH}$ footprint/volume; $\mathrm{CMH}$ operating temperature range; $\mathrm{H}_{2}$ equilibrium pressure of the $\mathrm{CMH} ; \mathrm{H}_{2}$ sorption kinetics of the $\mathrm{CMH}$ as a function of temperature and; the amount of FC waste heat available. The supply of $\mathrm{H}_{2}$ from CMHs with operating temperatures below $\sim 250{ }^{\circ} \mathrm{C}$ requires only modest energy input where simple heat transfer solutions with low-efficiency, but low-cost, can be implemented. In principle, metal hydrides that operate at either low- or high-temperature are suitable for use with high-temperature fuel cells (MCFCs and SOFCs).

Figure 5 shows that, in general, the classic intermetallic hydrides are suitable for use with lowand moderate-temperature FCs (i.e., $\sim 250^{\circ} \mathrm{C}$ and below), including LT- and HT-PEMFCs, AFCs and PAFCs. In contrast, of all the CMH systems, only $\mathrm{NaAlH}_{4}$ and the $\mathrm{Mg}\left(\mathrm{NH}_{2}\right)_{2}+2 \mathrm{LiH}$ system can theoretically operate at low enough temperatures for use with a LT-PEMFC. However, in practice, these systems only display sufficient $\mathrm{H}_{2}$ sorption kinetics above $\sim 10{ }^{\circ} \mathrm{C}$, which excludes their practical use with LT-PEMFCs. The CMH systems based on $\mathrm{Na}_{3} \mathrm{AlH}_{6}, \mathrm{Na}_{2} \mathrm{LiAlH}_{6}$ and $\mathrm{KAlH}_{4}+\mathrm{LiCl}$ can also, in theory, operate with the low- and moderate-temperature FCs other than LT-PEMFCs. Of these systems, uncatalyzed $\mathrm{KAlH}_{4}-\mathrm{LiCl}$ also has kinetic limitations with the maximum rate of $\mathrm{H}_{2}$ release only achieved at $230^{\circ} \mathrm{C}$ [247]. Figure 5 also shows that all of the CMHs can potentially be used for $\mathrm{H}_{2}$ storage when paired with MCFCs and SOFCs. The choice of $\mathrm{CMH}$ would then be determined by the best match of the FC operating conditions, $\mathrm{CMH}$ properties and the application requirements.

To summarize, the high thermal stability of $\mathrm{CMHs}$ makes them attractive as heat storage materials as the energy density may be tenfold higher than current state-of-the-art materials. Secondly, CMHs in combination with a fuel cell for stationary energy storage, have several advantages compared to commercially available Li-ion batteries, e.g., no self-discharge, higher safety and energy density.

\section{Conclusions}

The chemistry of complex metal hydrides is extremely diverse, and has provided a wide range of novel materials in the past decade. Especially metal borohydrides with gravimetric hydrogen density of $>10$ mass $\%$, have received increasing interest as solid state hydrogen storage materials. Furthermore, these materials have extremely rich chemistry based on structural flexibility and a wide range of elemental compositions.

The potential of complex metal hydrides for use in a range of new applications have also been highlighted in this review, see Figure 6. Examples are: as electrodes or electrolytes in solid state batteries, e.g., the high-temperature polymorph of $\mathrm{Na}_{2} \mathrm{~B}_{12} \mathrm{H}_{12}$ which has a high ionic conductivity; thermal energy storage, e.g., at $507.5^{\circ} \mathrm{C} \mathrm{NaBH}_{4}$ has theoretical gravimetric and volumetric heat storage capacities of $5176 \mathrm{~kJ} / \mathrm{kg}$ and $5559 \mathrm{~kJ} / \mathrm{L}$, respectively; and fuel cell applications. Indeed, many other properties, e.g., optical and magnetic properties are also promising and have been discovered in the metal borohydrides $\mathrm{CsEu}\left(\mathrm{BH}_{4}\right)_{3}$ and $\mathrm{K}_{2} \mathrm{Gd}\left(\mathrm{BH}_{4}\right)_{5}$ as fluorescent and magnetocaloric properties, respectively $[123,289]$. Furthermore, the metal closo-boranes, $\mathrm{Ag}_{2} \mathrm{~B}_{10} \mathrm{H}_{10}$ and $\mathrm{Ag}_{2} \mathrm{~B}_{12} \mathrm{H}_{12}$, display photosensitivity analogous to silver halides and forms silver nanofilaments upon electron beam exposure [201].

Hopefully, new metal borohydrides will be possible to design with desired chemical composition, atomic coordination, and exciting properties, based on the extensive knowledge about novel compounds, e.g., new combinations of light elements and boron, nitrogen or aluminum in complexes with hydrogen may lead to new interesting possibilities in applications. 


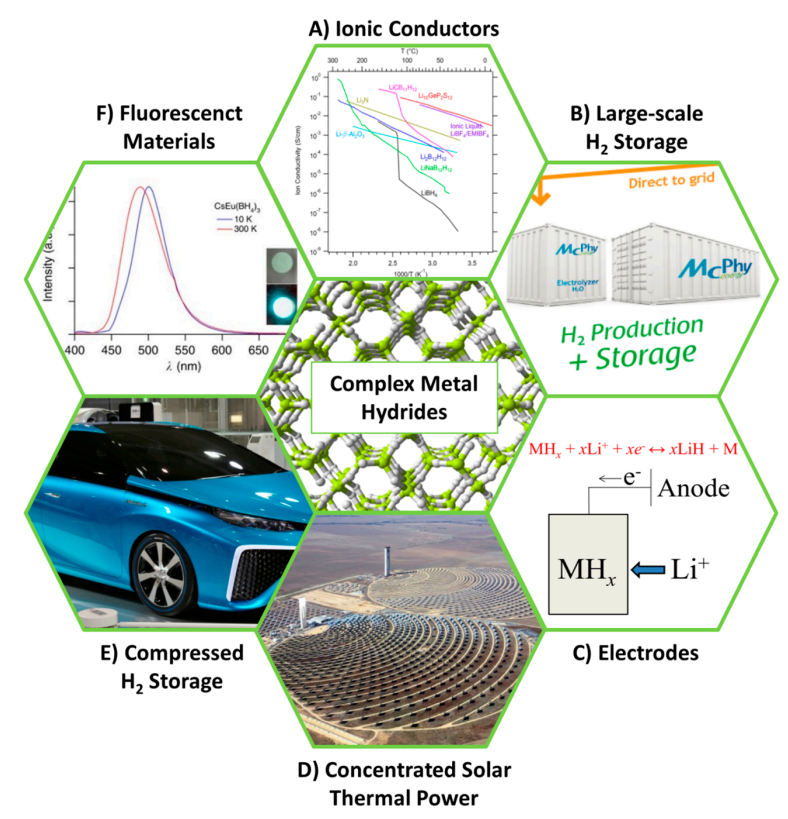

Figure 6. State-of-the-art applications for complex metal hydrides [1,123,290-292].

Acknowledgments: The work was supported by the Aarhus University Research Foundations (AUFF), the Danish National Research Foundation, Center for Materials Crystallography (DNRF93), The Innovation Fund Denmark (project HyFill-Fast), Danish Council for Independent Research, DFF-4181-00462 (HyNanoBorN), Energistyrelsen, EUDP (64013-0136), the Danish Research Council for Nature and Universe (Danscatt), and by JSPS KAKENHI Grant Number 15KK0212 and the International Institute for Carbon Neutral Energy Research (WPI-I2CNER), sponsored by the Japanese Ministry of Education, Culture, Sports, Science and Technology. CEB and DS acknowledge the financial support of the Australian Research Council (ARC) for ARC Linkage grant LP120101848 and LP150100730. Finally, the authors are grateful to the Carlsberg Foundation.

Conflicts of Interest: The authors declare no conflict of interest.

\section{References}

1. Ley, M.B.; Jepsen, L.H.; Lee, Y.-S.; Cho, Y.W.; Bellosta von Colbe, J.M.; Dornheim, M.; Rokni, M.; Jensen, J.O.; Sloth, M.; Filinchuk, Y.; et al. Complex hydrides for hydrogen storage-New perspectives. Mater. Today 2014, 17, 122-128. [CrossRef]

2. Rude, L.H.; Nielsen, T.K.; Ravnsbæk, D.B.; Bösenberg, U.; Ley, M.B.; Richter, B.; Arnbjerg, L.M.; Dornheim, M.; Filinchuk, Y.; Besenbacher, F. Tailoring properties of borohydrides for hydrogen storage: A review. Phys. Status Solidi A 2011, 208, 1754-1773. [CrossRef]

3. Paskevicius, M.; Jepsen, L.H.; Schouwink, P.; Černý, R.; Ravnsbæk, D.B.; Filinchuk, Y.; Dornheim, M.; Besenbacher, F.; Jensen, T.R. Metal borohydrides and derivatives-Synthesis, structure and properties. Chem. Soc. Rev. 2017, 46, 1565-1634. [CrossRef] [PubMed]

4. Jepsen, L.H.; Ley, M.B.; Lee, Y.-S.; Cho, Y.W.; Dornheim, M.; Jensen, J.O.; Filinchuk, Y.; Jørgensen, J.E.; Besenbacher, F.; Jensen, T.R. Boron-nitrogen based hydrides and reactive composites for hydrogen storage. Mater. Today 2014, 17, 129-135. [CrossRef]

5. Bogdanović, B.; Schwickardi, M. Ti-doped alkali metal aluminium hydrides as potential novel reversible hydrogen storage materials. J. Alloys Compd. 1997, 253-254, 1-9. [CrossRef]

6. Züttel, A.; Wenger, P.; Rentsch, S.; Sudan, P.; Mauron, P.; Emmenegger, C. LiBH4 a new hydrogen storage material. J. Power Sources 2003, 118, 1-7. [CrossRef]

7. Chen, P.; Xiong, Z.; Luo, J.; Lin, J.; Tan, K.L. Interaction of hydrogen with metal nitrides and imides. Nature 2002, 420, 302-304. [CrossRef] [PubMed]

8. Soulié, J.-P.; Renaudin, G.; Černý, R.; Yvon, K. Lithium boro-hydride LiBH4: I. Crystal structure. J. Alloys Compd. 2002, 346, 200-205. [CrossRef] 
9. Wang, J.; Li, H.-W.; Chen, P. Amides and borohydrides for high-capacity solid-state hydrogen storage-Materials design and kinetic improvements. MRS Bull. 2013, 38, 480-487. [CrossRef]

10. Nakamori, Y.; Kitahara, G.; Orimo, S. Synthesis and dehydriding studies of Mg-N-H systems. J. Power Sources 2004, 138, 309-312. [CrossRef]

11. Leng, H.Y.; Ichikawa, T.; Hino, S.; Hanada, N.; Isobe, S.; Fujii, H. New Metal-N-H System Composed of $\mathrm{Mg}\left(\mathrm{NH}_{2}\right)_{2}$ and $\mathrm{LiH}$ for Hydrogen Storage. J. Phys. Chem. B 2004, 108, 8763-8765. [CrossRef]

12. Luo, W. (LiNH2-MgH2): A viable hydrogen storage system. J. Alloys Compd. 2004, 381, 284-287. [CrossRef]

13. Paik, B.; Li, H.-W.; Wang, J.; Akiba, E. A Li-Mg-N-H composite as $\mathrm{H}_{2}$ storage material: A case study with $\mathrm{Mg}\left(\mathrm{NH}_{2}\right)_{2}-4 \mathrm{LiH}-\mathrm{LiNH}_{2}$. Chem. Commun. 2015, 51, 10018-10021. [CrossRef] [PubMed]

14. Xiong, Z.; Hu, J.; Wu, G.; Chen, P.; Luo, W.; Gross, K.; Wang, J. Thermodynamic and kinetic investigations of the hydrogen storage in the Li-Mg-N-H system. J. Alloys Compd. 2005, 398, 235-239. [CrossRef]

15. Torre, F.; Valentoni, A.; Milanese, C.; Pistidda, C.; Marini, A.; Dornheim, M.; Enzo, S.; Mulas, G.; Garroni, S. Kinetic improvement on the $\mathrm{CaH}_{2}$-catalyzed $\mathrm{Mg}\left(\mathrm{NH}_{2}\right)_{2}+2 \mathrm{LiH}$ system. J. Alloys Compd. 2015, 645, S284-S287. [CrossRef]

16. Shaw, L.L.; Ren, R.; Markmaitree, T.; Osborn, W. Effects of mechanical activation on dehydrogenation of the lithium amide and lithium hydride system. J. Alloys Compd. 2008, 448, 263-271. [CrossRef]

17. Liu, Y.; Zhong, K.; Luo, K.; Gao, M.; Pan, H.; Wang, Q. Size-Dependent Kinetic Enhancement in Hydrogen Absorption and Desorption of the Li-Mg-N-H System. J. Am. Chem. Soc. 2009, 131, 1862-1870. [CrossRef] [PubMed]

18. Cao, H.; Santoru, A.; Pistidda, C.; M. Richter, T.M.; Chaudhary, A.-L.; Gizer, G.; Niewa, R.; Chen, P.; Klassen, T.; Dornheim, M. New synthesis route for ternary transition metal amides as well as ultrafast amide-hydride hydrogen storage materials. Chem. Commun. 2016, 52, 5100-5103. [CrossRef] [PubMed]

19. Cao, H.; Richter, T.M.M.; Pistidda, C.; Chaudhary, A.-L.; Santoru, A.; Gizer, G.; Niewa, R.; Chen, P.; Klassen, T.; Dornheim, M. Ternary Amides Containing Transition Metals for Hydrogen Storage: A Case Study with Alkali Metal Amidozincates. ChemSusChem 2015, 8, 3777-3782. [CrossRef] [PubMed]

20. Cao, H.; Pistidda, C.; Richter, T.M.M.; Santoru, A.; Milanese, C.; Garroni, S.; Bednarcik, J.; Chaudhary, A.-L.; Gizer, G.; Liermann, H.-P.; et al. In situ X-ray diffraction studies on the de/rehydrogenation processes of the $\mathrm{K}_{2}\left[\mathrm{Zn}\left(\mathrm{NH}_{2}\right)_{4}\right]-8 \mathrm{LiH}$ system. J. Phys. Chem. C 2017, 121, 1546-1551. [CrossRef]

21. Janot, R.; Eymery, J.-B.; Tarascon, J.-M. Decomposition of $\mathrm{LiAl}\left(\mathrm{NH}_{2}\right)_{4}$ and Reaction with $\mathrm{LiH}$ for a Possible Reversible Hydrogen Storage. J. Phys. Chem. C 2007, 111, 2335-2340. [CrossRef]

22. Jepsen, L.H.; Wang, P.; Wu, G.; Xiong, Z.; Besenbacher, F.; Chen, P.; Jensen, T.R. Thermal decomposition of sodium amide, $\mathrm{NaNH}_{2}$, and sodium amide hydroxide composites, $\mathrm{NaNH}_{2}-\mathrm{NaOH}$. Phys. Chem. Chem. Phys. 2016, 18, 25257-25264. [CrossRef] [PubMed]

23. Lide, D.R. CRC Handbook of Chemistry and Physics, 88th ed.; CRC Press: Boca Raton, FL, USA, 25 June 2007; ISBN 0-8493-0488-1.

24. Orimo, S.I.; Nakamori, Y.; Eliseo, J.R.; Züttel, A.; Jensen, C.M. Complex Hydrides for Hydrogen Storage. Chem. Rev. 2007, 107, 4111-4132. [CrossRef] [PubMed]

25. Mauron, P.; Buchter, F.; Friedrichs, O.; Remhof, A.; Bielmann, M.; Zwicky, C.N.; Zuttel, A. Stability and Reversibility of LiBH4. J. Phys. Chem. B 2008, 112, 906-910. [CrossRef] [PubMed]

26. Martelli, P.; Caputo, R.; Remhof, A.; Mauron, P.; Borgschulte, A.; Züttel, A. Stability and Decomposition of NaBH4. J. Phys. Chem. C 2010, 114, 7173-7177. [CrossRef]

27. Dornheim, M. Thermodynamics of Metal Hydrides: Tailoring Reaction Enthalpies of Hydrogen Storage Materials; InTech: Rijeka, Croatia, 2011; ISBN 978-953-307-563-1.

28. Na Ranong, C.; Höhne, M.; Franzen, J.; Hapke, J.; Fieg, G.; Dornheim, M.; Eigen, N.; Bellosta von Colbe, J.M.; Metz, O. Concept, Design and Manufacture of a Prototype Hydrogen Storage Tank Based on Sodium Alanate. Chem. Eng. Technol. 2009, 32, 1154-1163. [CrossRef]

29. Isobe, S.; Ichikawa, T.; Tokoyoda, K.; Hanada, N.; Leng, H.; Fujii, H.; Kojima, Y. Evaluation of enthalpy change due to hydrogen desorption for lithium amide/imide system by differential scanning calorimetry. Thermochim. Acta 2008, 468, 35-38. [CrossRef]

30. Kojima, Y.; Kawai, Y. IR characterizations of lithium imide and amide. J. Alloys Compd. 2005, 395, $236-239$. [CrossRef]

31. Ichikawa, T.; Isobe, S.; Hanada, N.; Fujii, H. Lithium nitride for reversible hydrogen storage. J. Alloys Compd. 2004, 365, 271-276. [CrossRef] 
32. Paskevicius, M.; Webb, J.; Pitt, M.P.; Blach, T.P.; Hauback, B.C.; Gray, E.; Buckley, C.E. Mechanochemical synthesis of aluminium nanoparticles and their deuterium sorption properties to $2 \mathrm{kbar}$. J. Alloys Compd. 2009, 481, 595-599. [CrossRef]

33. Sartori, S.; Opalka, S.M.; Løvvik, O.M.; Guzik, M.N.; Tang, X.; Hauback, B.C. Experimental studies of $\alpha$-AlD3 and $\alpha^{\prime}$-AlD3 versus first-principles modelling of the alane isomorphs. J. Mater. Chem. 2008, 18, 2361. [CrossRef]

34. Sandrock, G.; Reilly, J.; Graetz, J.; Zhou, W.-M.; Johnson, J.; Wegrzyn, J. Accelerated thermal decomposition of AlH3 for hydrogen-fueled vehicles. Appl. Phys. A 2005, 80, 687-690. [CrossRef]

35. Ikeda, K.; Ohshita, H.; Kaneko, N.; Zhang, J.; Yonemura, M.; Otomo, T.; Suzuya, K.; Yukawa, H.; Morinaga, M.; Li, H.-W.; et al. Structural and Hydrogen Desorption Properties of Aluminum Hydride. Mater. Trans. 2011, 52, 598-601. [CrossRef]

36. Finholt, A.E.; Bond, A.C.; Schlesinger, H.I. Lithium Aluminum Hydride, Aluminum Hydride and Lithium Gallium Hydride, and Some of their Applications in Organic and Inorganic Chemistry ${ }^{1}$. J. Am. Chem. Soc. 1947, 69, 1199-1203. [CrossRef]

37. Hauback, B.C. Structures of aluminium-based light weight hydrides. Z. Krist. 2009, 223, 636-648. [CrossRef]

38. Brower, F.M.; Matzek, N.E.; Reigler, P.F.; Rinn, H.W.; Roberts, C.B.; Schmidt, D.L.; Snover, J.A.; Terada, K. Preparation and properties of aluminum hydride. J. Am. Chem. Soc. 1976, 98, 2450-2453. [CrossRef]

39. Turley, J.W.; Rinn, H.W. Crystal structure of aluminum hydride. Inorg. Chem. 1969, 8, 18-22. [CrossRef]

40. Brinks, H.W.; Istad-Lem, A.; Hauback, B.C. Mechanochemical Synthesis and Crystal Structure of $\alpha^{\prime}$-AlD3 and $\alpha$-AlD3. J. Phys. Chem. B 2006, 110, 25833-25837. [CrossRef] [PubMed]

41. Brinks, H.W.; Langley, W.; Jensen, C.M.; Graetz, J.; Reilly, J.J.; Hauback, B.C. Synthesis and crystal structure of $\beta$-AlD3. J. Alloys Compd. 2007, 433, 180-183. [CrossRef]

42. Brinks, H.W.; Brown, C.; Jensen, C.M.; Graetz, J.; Reilly, J.J.; Hauback, B.C. The crystal structure of $\gamma$-AlD3. J. Alloys Compd. 2007, 441, 364-367. [CrossRef]

43. Yartys, V.A.; Denys, R.V.; Maehlen, J.P.; Frommen, C.; Fichtner, M.; Bulychev, B.M.; Emerich, H. Double-Bridge Bonding of Aluminium and Hydrogen in the Crystal Structure of $\gamma$-AlH3. Inorg. Chem. 2007, 46, 1051-1055. [CrossRef] [PubMed]

44. Konovalov, S.K.; Bulychev, B.M. The P,T-State Diagram and Solid Phase Synthesis of Aluminum Hydride. Inorg. Chem. 1995, 34, 172-175. [CrossRef]

45. Sartori, S.; Istad-Lem, A.; Brinks, H.W.; Hauback, B.C. Mechanochemical synthesis of alane. Int. J. Hydrogen Energy 2009, 34, 6350-6356. [CrossRef]

46. Paskevicius, M.; Sheppard, D.A.; Buckley, C.E. Characterisation of mechanochemically synthesised alane (AlH3) nanoparticles. J. Alloys Compd. 2009, 487, 370-376. [CrossRef]

47. Gupta, S.; Kobayashi, T.; Hlova, I.Z.; Goldston, J.F.; Pruski, M.; Pecharsky, V.K. Solvent-free mechanochemical synthesis of alane, AlH3: Effect of pressure on the reaction pathway. Green Chem. 2014, 16, 4378-4388. [CrossRef]

48. Dinh, L.V.; Knight, D.A.; Paskevicius, M.; Buckley, C.E.; Zidan, R. Novel methods for synthesizing halide-free alane without the formation of adducts. Appl. Phys. A 2012, 107, 173-181. [CrossRef]

49. Graetz, J.; Chaudhuri, S.; Lee, Y.; Vogt, T.; Muckerman, J.T.; Reilly, J.J. Pressure-induced structural and electronic changes in $\alpha$-AlH3. Phys. Rev. B 2006, 74, 214114. [CrossRef]

50. Graetz, J.; Reilly, J.J. Decomposition Kinetics of the AlH3 Polymorphs. J. Phys. Chem. B 2005, 109, 22181-22185. [CrossRef] [PubMed]

51. Sato, T.; Ikeda, K.; Li, H.-W.; Yukawa, H.; Morinaga, M.; Orimo, S. Direct Dry Syntheses and Thermal Analyses of a Series of Aluminum Complex Hydrides. Mater. Trans. 2009, 50, 182-186. [CrossRef]

52. Graetz, J. New approaches to hydrogen storage. Chem. Soc. Rev. 2009, 38, 73. [CrossRef] [PubMed]

53. Ashby, E.C.; Brendel, G.J.; Redman, H.E. Direct Synthesis of Complex Metal Hydrides. Inorg. Chem. 1963, 2, 499-504. [CrossRef]

54. Clasen, H. Alanat-Synthese aus den Elementen und ihre Bedeutung. Angew. Chem. 1961, 73, 322-331. [CrossRef]

55. Balema, V.P.; Balema, L. Missing pieces of the puzzle or about some unresolved issues in solid state chemistry of alkali metal aluminohydrides. Phys. Chem. Chem. Phys. 2005, 7, 1310-1314. [CrossRef] [PubMed]

56. Dilts, J.A.; Ashby, E.C. Thermal decomposition of complex metal hydrides. Inorg. Chem. 1972, 11, 1230-1236. [CrossRef] 
57. Arnbjerg, L.M.; Jensen, T.R. New compounds in the potassium-aluminium-hydrogen system observed during release and uptake of hydrogen. Int. J. Hydrogen Energy 2012, 37, 345-356. [CrossRef]

58. Ares, J.R.; Aguey-Zinsou, K.-F.; Porcu, M.; Sykes, J.M.; Dornheim, M.; Klassen, T.; Bormann, R. Thermal and mechanically activated decomposition of LiAlH4. Mater. Res. Bull. 2008, 43, 1263-1275. [CrossRef]

59. Block, J.; Gray, A.P. The Thermal Decomposition of Lithium Aluminum Hydride. Inorg. Chem. 1965, 4, 304-305. [CrossRef]

60. Chen, J.; Kuriyama, N.; Xu, Q.; Takeshita, H.T.; Sakai, T. Reversible Hydrogen Storage via Titanium-Catalyzed $\mathrm{LiAlH}_{4}$ and $\mathrm{Li}_{3} \mathrm{AlH}_{6}$. J. Phys. Chem. B 2001, 105, 11214-11220. [CrossRef]

61. Dymova, T.N.; Aleksandrov, D.P.; Konoplev, V.N.; Silina, T.A.; Sizareva, A.S. Spontaneous and thermal-decomposition of Lithium Tetrahydroaluminate LiAlH4-the promoting effect of mechanochemical action on the process. Koord. Khimiya 1994, 20, 279-285.

62. Andreasen, A.; Vegge, T.; Pedersen, A.S. Dehydrogenation kinetics of as-received and ball-milled. J. Solid State Chem. 2005, 178, 3672-3678. [CrossRef]

63. Balema, V.P.; Dennis, K.W.; Pecharsky, V.K. Rapid solid-state transformation of tetrahedral $\left[\mathrm{AlH}_{4}\right]^{-}$into $^{-}$ octahedral $\left[\mathrm{AlH}_{6}\right]_{3}{ }^{-}$in lithium aluminohydride. Chem. Commun. 2000, 1665-1666. [CrossRef]

64. Balema, V.P.; Wiench, J.W.; Dennis, K.W.; Pruski, M.; Pecharsky, V.K. Titanium catalyzed solid-state transformations in $\mathrm{LiAlH}_{4}$ during high-energy ball-milling. J. Alloys Compd. 2001, 329, 108-114. [CrossRef]

65. Balema, V.P.; Pecharsky, V.K.; Dennis, K.W. Solid state phase transformations in $\mathrm{LiAlH}_{4}$ during high-energy ball-milling. J. Alloys Compd. 2000, 313, 69-74. [CrossRef]

66. Blanchard, D.; Brinks, H.W.; Hauback, B.C.; Norby, P. Desorption of $\mathrm{LiAlH}_{4}$ with Ti- and V-based additives. Mater. Sci. Eng. B 2004, 108, 54-59. [CrossRef]

67. Lai, Q.; Paskevicius, M.; Sheppard, D.A.; Buckley, C.E.; Thornton, A.W.; Hill, M.R.; Gu, Q.; Mao, J.; Huang, Z.; Liu, H.K.; et al. Hydrogen Storage Materials for Mobile and Stationary Applications: Current State of the Art. ChemSusChem 2015, 8, 2789-2825. [CrossRef] [PubMed]

68. Liu, X.; McGrady, G.S.; Langmi, H.W.; Jensen, C.M. Facile Cycling of Ti-Doped $\mathrm{LiAlH}_{4}$ for High Performance Hydrogen Storage. J. Am. Chem. Soc. 2009, 131, 5032-5033. [CrossRef] [PubMed]

69. Graetz, J.; Wegrzyn, J.; Reilly, J.J. Regeneration of Lithium Aluminum Hydride. J. Am. Chem. Soc. 2008, 130, 17790-17794. [CrossRef] [PubMed]

70. Pitt, M.P.; Vullum, P.E.; Sørby, M.H.; Emerich, H.; Paskevicius, M.; Buckley, C.E.; Walmsley, J.C.; Holmestad, R.; Hauback, B.C. Hydrogen Absorption Kinetics of the Transition-Metal-Chloride-Enhanced NaAlH4 System. J. Phys. Chem. C 2012, 116, 14205-14217. [CrossRef]

71. Nielsen, T.K.; Javadian, P.; Polanski, M.; Besenbacher, F.; Bystrzycki, J.; Skibsted, J.; Jensen, T.R. Nanoconfined NaAlH4: Prolific effects from increased surface area and pore volume. Nanoscale 2014, 6, 599-607. [CrossRef] [PubMed]

72. Nielsen, T.K.; Javadian, P.; Polanski, M.; Besenbacher, F.; Bystrzycki, J.; Jensen, T.R. Nanoconfined NaAlH N $^{2}$ Determination of distinct prolific effects from pore size, crystallite size, and surface interactions. J. Phys. Chem. C 2012, 116, 21046-21051. [CrossRef]

73. Nielsen, T.K.; Polanski, M.; Zasada, D.; Javadian, P.; Besenbacher, F.; Bystrzycki, J.; Skibsted, J.; Jensen, T.R. Improved Hydrogen Storage Kinetics of Nanoconfined $\mathrm{NaAlH}_{4}$ Catalyzed with $\mathrm{TiCl}_{3} \mathrm{Nanoparticles}$ ACS Nano 2011, 5, 4056-4064. [CrossRef] [PubMed]

74. Jensen, C.M.; Gross, K.J. Development of catalytically enhanced sodium aluminum hydride as a hydrogen-storage material. Appl. Phys. A 2001, 72, 213-219. [CrossRef]

75. Zidan, R.A.; Takara, S.; Hee, A.G.; Jensen, C.M. Hydrogen cycling behavior of zirconium and titanium-zirconium-doped sodium aluminum hydride. J. Alloys Compd. 1999, 285, 119-122. [CrossRef]

76. Bogdanović, B.; Felderhoff, M.; Pommerin, A.; Schüth, F.; Spielkamp, N. Advanced Hydrogen-Storage Materials Based on Sc-, Ce-, and Pr-Doped NaAlH 4 . Adv. Mater. 2006, 18, 1198-1201. [CrossRef]

77. Pitt, M.P.; Paskevicius, M.; Webb, C.J.; Sørby, M.H.; Delleda, S.; Jensen, T.R.; Hauback, B.C.; Buckley, C.E.; Gray, E.M. Nanoscopic $\mathrm{Al}_{1-x} \mathrm{Ce}_{x}$ phases in the $\mathrm{NaH}+\mathrm{Al}+0.02 \mathrm{CeCl}_{3}$ system. Int. J. Hydrogen Energy 2011, 36, 8403-8411. [CrossRef]

78. Fichtner, M.; Fuhr, O. Synthesis and structures of magnesium alanate and two solvent adducts. J. Alloys Compd. 2002, 345, 286-296. [CrossRef]

79. Fichtner, M.; Frommen, C.; Fuhr, O. Synthesis and Properties of Calcium Alanate and Two Solvent Adducts. Inorg. Chem. 2005, 44, 3479-3484. [CrossRef] [PubMed] 
80. Pommerin, A.; Wosylus, A.; Felderhoff, M.; Schüth, F.; Weidenthaler, C. Synthesis, Crystal Structures, and Hydrogen-Storage Properties of $\mathrm{Eu}\left(\mathrm{AlH}_{4}\right)_{2}$ and $\mathrm{Sr}\left(\mathrm{AlH}_{4}\right)_{2}$ and of Their Decomposition Intermediates, EuAlH ${ }_{5}$ and $\mathrm{SrAlH}_{5}$. Inorg. Chem. 2012, 51, 4143-4150. [CrossRef] [PubMed]

81. Løvvik, O.M.; Swang, O.; Opalka, S.M. Modeling alkali alanates for hydrogen storage by density-functional band-structure calculations. J. Mater. Res. 2005, 20, 3199-3213. [CrossRef]

82. Arroyo y de Dompablo, M.E.; Ceder, G. First principles investigations of complex hydrides $\mathrm{AMH}_{4}$ and $\mathrm{A}_{3} \mathrm{MH}_{6}(\mathrm{~A}=\mathrm{Li}, \mathrm{Na}, \mathrm{K}, \mathrm{M}=\mathrm{B}, \mathrm{Al}, \mathrm{Ga})$ as hydrogen storage systems. J. Alloys Compd. 2004, 364, 6-12. [CrossRef]

83. Ares, J.R.; Aguey-Zinsou, K.-F.; Leardini, F.; Ferrer, I.J.; Fernandez, J.-F.; Guo, Z.-X.; Sánchez, C. Hydrogen Absorption/Desorption Mechanism in Potassium Alanate $\left(\mathrm{KAlH}_{4}\right)$ and Enhancement by TiCl3 Doping. J. Phys. Chem. C 2009, 113, 6845-6851. [CrossRef]

84. Morioka, H.; Kakizaki, K.; Chung, S.-C.; Yamada, A. Reversible hydrogen decomposition of $\mathrm{KAlH}_{4}$. J. Alloys Compd. 2003, 353, 310-314. [CrossRef]

85. Černý, R.; Schouwink, P. The crystal chemistry of inorganic metal borohydrides and their relation to metal oxides. Acta Crystallogr. B 2015, 71, 619-640. [CrossRef] [PubMed]

86. Züttel, A.; Rentsch, S.; Fischer, P.; Wenger, P.; Sudan, P.; Mauron, P.; Emmenegger, C. Hydrogen storage properties of $\mathrm{LiBH}_{4}$. J. Alloys Compd. 2003, 356-357, 515-520. [CrossRef]

87. Nakamori, Y.; Orimo, S. Destabilization of Li-based complex hydrides. J. Alloys Compd. 2004, 370, $271-275$. [CrossRef]

88. Hartman, M.R.; Rush, J.J.; Udovic, T.J.; Bowman, R.C., Jr.; Hwang, S.-J. Structure and vibrational dynamics of isotopically labeled lithium borohydride using neutron diffraction and spectroscopy. J. Solid State Chem. 2007, 180, 1298-1305. [CrossRef]

89. Filinchuk, Y.; Chernyshov, D.; Cerny, R. Lightest Borohydride Probed by Synchrotron X-ray Diffraction: Experiment Calls for a New Theoretical Revision. J. Phys. Chem. C 2008, 112, 10579-10584. [CrossRef]

90. Eberle, U.; Felderhoff, M.; Schüth, F. Chemical and Physical Solutions for Hydrogen Storage. Angew. Chem. Int. Ed. 2009, 48, 6608-6630. [CrossRef] [PubMed]

91. Grube, E.; Olesen, C.H.; Ravnsbæk, D.B.; Jensen, T.R. Barium borohydride chlorides: Synthesis, crystal structures and thermal properties. Dalton Trans. 2016, 45, 8291-8299. [CrossRef] [PubMed]

92. Ravnsbæk, D.B.; Nickels, E.A.; Černý, R.; Olesen, C.H.; David, W.I.F.; Edwards, P.P.; Filinchuk, Y.; Jensen, T.R. Novel Alkali Earth Borohydride $\mathrm{Sr}\left(\mathrm{BH}_{4}\right)_{2}$ and Borohydride-Chloride $\mathrm{Sr}\left(\mathrm{BH}_{4}\right) \mathrm{Cl}$. Inorg. Chem. 2013, 52, 10877-10885. [CrossRef] [PubMed]

93. Sharma, M.; Didelot, E.; Spyratou, A.; Lawson Daku, L.M.; Černý, R.; Hagemann, H. Halide Free $\mathrm{M}\left(\mathrm{BH}_{4}\right)_{2}$ $(\mathrm{M}=\mathrm{Sr}, \mathrm{Ba}$, and Eu) Synthesis, Structure, and Decomposition. Inorg. Chem. 2016, 55, 7090-7097. [CrossRef] [PubMed]

94. Filinchuk, Y.; Richter, B.; Jensen, T.R.; Dmitriev, V.; Chernyshov, D.; Hagemann, H. Porous and Dense Magnesium Borohydride Frameworks: Synthesis, Stability, and Reversible Absorption of Guest Species. Angew. Chem. Int. Ed. 2011, 50, 11162-11166. [CrossRef] [PubMed]

95. Filinchuk, Y.; Černý, R.; Hagemann, H. Insight into $\mathrm{Mg}\left(\mathrm{BH}_{4}\right)_{2}$ with Synchrotron X-ray Diffraction: Structure Revision, Crystal Chemistry, and Anomalous Thermal Expansion. Chem. Mater. 2009, 21, 925-933. [CrossRef]

96. Her, J.-H.; Stephens, P.W.; Gao, Y.; Soloveichik, G.L.; Rijssenbeek, J.; Andrus, M.; Zhao, J.-C. Structure of unsolvated magnesium borohydride $\mathrm{Mg}\left(\mathrm{BH}_{4}\right)_{2}$. Acta Crystallogr. B 2007, 63, 561-568. [CrossRef] [PubMed]

97. Pitt, M.P.; Webb, C.J.; Paskevicius, M.; Sheptyakov, D.; Buckley, C.E.; Gray, E.M. In Situ Neutron Diffraction Study of the Deuteration of Isotopic $\mathrm{Mg}_{11} \mathrm{~B}_{2}$. J. Phys. Chem. C 2011, 115, 22669-22679. [CrossRef]

98. Paskevicius, M.; Pitt, M.P.; Webb, C.J.; Sheppard, D.A.; Filsø, U.; Gray, E.M.; Buckley, C.E. In-Situ X-ray Diffraction Study of $\gamma-\mathrm{Mg}\left(\mathrm{BH}_{4}\right)_{2}$ Decomposition. J. Phys. Chem. C 2012, 116, 15231-15240. [CrossRef]

99. David, W.I.F.; Callear, S.K.; Jones, M.O.; Aeberhard, P.C.; Culligan, S.D.; Pohl, A.H.; Johnson, S.R.; Ryan, K.R.; Parker, J.E.; Edwards, P.P.; et al. The structure, thermal properties and phase transformations of the cubic polymorph of magnesium tetrahydroborate. Phys. Chem. Chem. Phys. 2012, 14, 11800-11807. [CrossRef] [PubMed]

100. Amieiro-Fonseca, A.; Ellis, S.R.; Nuttall, C.J.; Hayden, B.E.; Guerin, S.; Purdy, G.; Soulié, J.-P.; Callear, S.K.; Culligan, S.D.; David, W.I.F.; et al. A multidisciplinary combinatorial approach for tuning promising hydrogen storage materials towards automotive applications. Faraday Discuss. 2011, 151, 369. [CrossRef] [PubMed] 
101. Li, H.-W.; Kikuchi, K.; Nakamori, Y.; Miwa, K.; Towata, S.; Orimo, S. Effects of ball milling and additives on dehydriding behaviors of well-crystallized $\mathrm{Mg}\left(\mathrm{BH}_{4}\right)_{2}$. Scr. Mater. 2007, 57, 679-682. [CrossRef]

102. Li, H.-W.; Miwa, K.; Ohba, N.; Fujita, T.; Sato, T.; Yan, Y.; Towata, S.; Chen, M.W.; Orimo, S. Formation of an intermediate compound with a $\mathrm{B}_{12} \mathrm{H}_{12}$ cluster: Experimental and theoretical studies on magnesium borohydride $\mathrm{Mg}\left(\mathrm{BH}_{4}\right)_{2}$. Nanotechnology 2009, 20, 204013. [CrossRef] [PubMed]

103. Li, H.-W.; Matsunaga, T.; Yan, Y.; Maekawa, H.; Ishikiriyama, M.; Orimo, S. Nanostructure-induced hydrogenation of layered compound $\mathrm{MgB}_{2}$. J. Alloys Compd. 2010, 505, 654-656. [CrossRef]

104. Roedern, E.; Jensen, T.R. Ammine-Stabilized Transition-Metal Borohydrides of Iron, Cobalt, and Chromium: Synthesis and Characterization. Inorg. Chem. 2015, 54, 10477-10482. [CrossRef] [PubMed]

105. Callini, E.; Szilágyi, P.Á.; Paskevicius, M.; Stadie, N.P.; Réhault, J.; Buckley, C.E.; Borgschulte, A.; Züttel, A. Stabilization of volatile $\mathrm{Ti}\left(\mathrm{BH}_{4}\right)_{3}$ by nano-confinement in a metal-organic framework. Chem. Sci. 2015, 7, 666-672. [CrossRef] [PubMed]

106. Rude, L.H.; Corno, M.; Ugliengo, P.; Baricco, M.; Lee, Y.-S.; Cho, Y.W.; Besenbacher, F.; Overgaard, J.; Jensen, T.R. Synthesis and Structural Investigation of $\mathrm{Zr}\left(\mathrm{BH}_{4}\right)_{4}$. J. Phys. Chem. C 2012, 116, 20239-20245. [CrossRef]

107. Nickels, E.A.; Jones, M.O.; David, W.I.F.; Johnson, S.R.; Lowton, R.L.; Sommariva, M.; Edwards, P.P. Tuning the Decomposition Temperature in Complex Hydrides: Synthesis of a Mixed Alkali Metal Borohydride. Angew. Chem. Int. Ed. 2008, 47, 2817-2819. [CrossRef] [PubMed]

108. Roedern, E.; Hansen, B.R.S.; Ley, M.B.; Jensen, T.R. Effect of Eutectic Melting, Reactive Hydride Composites, and Nanoconfinement on Decomposition and Reversibility of $\mathrm{LiBH}_{4}-\mathrm{KBH}_{4}$. J. Phys. Chem. C 2015, 119, 25818-25825. [CrossRef]

109. Jensen, S.R.H.; Jepsen, L.H.; Skibsted, J.; Jensen, T.R. Phase Diagram for the $\mathrm{NaBH}_{4}-\mathrm{KBH}_{4}$ System and the Stability of a $\mathrm{Na}_{1-\mathrm{x}} \mathrm{K}_{\mathrm{x}} \mathrm{BH}_{4}$ Solid Solution. J. Phys. Chem. C 2015, 119, 27919-27929. [CrossRef]

110. Nakamori, Y.; Miwa, K.; Ninomiya, A.; Li, H.; Ohba, N.; Towata, S.; Züttel, A.; Orimo, S. Correlation between thermodynamical stabilities of metal borohydrides and cation electronegativites: First-principles calculations and experiments. Phys. Rev. B 2006, 74, 45126. [CrossRef]

111. Li, H.-W.; Orimo, S.; Nakamori, Y.; Miwa, K.; Ohba, N.; Towata, S.; Züttel, A. Materials designing of metal borohydrides: Viewpoints from thermodynamical stabilities. J. Alloys Compd. 2007, 446-447, 315-318. [CrossRef]

112. Ravnsbæk, D.; Filinchuk, Y.; Cerenius, Y.; Jakobsen, H.J.; Besenbacher, F.; Skibsted, J.; Jensen, T.R. A Series of Mixed-Metal Borohydrides. Angew. Chem. Int. Ed. 2009, 48, 6659-6663. [CrossRef] [PubMed]

113. Ravnsbæk, D.B.; Frommen, C.; Reed, D.; Filinchuk, Y.; Sørby, M.; Hauback, B.C.; Jakobsen, H.J.; Book, D.; Besenbacher, F.; Skibsted, J.; et al. Structural studies of lithium zinc borohydride by neutron powder diffraction, Raman and NMR spectroscopy. J. Alloys Compd. 2011, 509, S698-S704. [CrossRef]

114. Černý, R.; Kim, K.C.; Penin, N.; D’Anna, V.; Hagemann, H.; Sholl, D.S. AZn $\mathrm{A}_{2}\left(\mathrm{BH}_{4}\right)_{5}(\mathrm{~A}=\mathrm{Li}, \mathrm{Na})$ and $\mathrm{NaZn}\left(\mathrm{BH}_{4}\right)_{3}$ : Structural Studies. J. Phys. Chem. C 2010, 114, 19127-19133. [CrossRef]

115. Ley, M.B.; Ravnsbæk, D.B.; Filinchuk, Y.; Lee, Y.-S.; Janot, R.; Cho, Y.W.; Skibsted, J.; Jensen, T.R. LiCe $\left(\mathrm{BH}_{4}\right)_{3} \mathrm{Cl}$, a New Lithium-Ion Conductor and Hydrogen Storage Material with Isolated Tetranuclear Anionic Clusters. Chem. Mater. 2012, 24, 1654-1663. [CrossRef]

116. Møller, K.T.; Ley, M.B.; Schouwink, P.; Černý, R.; Jensen, T.R. Synthesis and thermal stability of perovskite alkali metal strontium borohydrides. Dalton Trans. 2016, 45, 831-840. [CrossRef] [PubMed]

117. Park, H.H.; Pezat, M.; Darriet, B. A new ternary hydride: $\mathrm{CsCaH}_{3}$. Rev. Chim. Minérale 1986, 23, $323-328$.

118. Bouamrane, A.; Laval, J.P.; Soulie, J.-P.; Bastide, J.P. Structural characterization of $\mathrm{NaMgH}_{2} \mathrm{~F}$ and $\mathrm{NaMgH}_{3}$. Mater. Res. Bull. 2000, 35, 545-549. [CrossRef]

119. Pottmaier, D.; Pinatel, E.R.; Vitillo, J.G.; Garroni, S.; Orlova, M.; Baró, M.D.; Vaughan, G.B.M.; Fichtner, M.; Lohstroh, W.; Baricco, M. Structure and Thermodynamic Properties of the $\mathrm{NaMgH}_{3}$ Perovskite: A Comprehensive Study. Chem. Mater. 2011, 23, 2317-2326. [CrossRef]

120. Ikeda, K.; Kogure, Y.; Nakamori, Y.; Orimo, S. Reversible hydriding and dehydriding reactions of perovskite-type hydride $\mathrm{NaMgH}_{3}$. Scr. Mater. 2005, 53, 319-322. [CrossRef]

121. Ikeda, K.; Kato, S.; Shinzato, Y.; Okuda, N.; Nakamori, Y.; Kitano, A.; Yukawa, H.; Morinaga, M.; Orimo, S. Thermodynamical stability and electronic structure of a perovskite-type hydride, $\mathrm{NaMgH}_{3}$. J. Alloys Compd. 2007, 446-447, 162-165. [CrossRef] 
122. Schouwink, P.; D’Anna, V.; Ley, M.B.; Daku, L.M.L.; Richter, B.; Jensen, T.R.; Hagemann, H.; Černý, R. Bimetallic Borohydrides in the System $\mathrm{M}\left(\mathrm{BH}_{4}\right)_{2}-\mathrm{KBH}_{4}(\mathrm{M}=\mathrm{Mg}$, Mn): On the Structural Diversity. J. Phys. Chem. C 2012, 116, 10829-10840. [CrossRef]

123. Schouwink, P.; Ley, M.B.; Tissot, A.; Hagemann, H.; Jensen, T.R.; Smrčok, L'.; Černý, R. Structure and properties of complex hydride perovskite materials. Nat. Commun. 2014, 5. [CrossRef] [PubMed]

124. Møller, K.T.; Jørgensen, M.; Fogh, A.S.; Jensen, T.R. Perovskite alkali metal samarium borohydrides: Crystal structures and thermal decomposition. Dalton Trans. 2017, 46, 11905-11912. [CrossRef] [PubMed]

125. Schouwink, P.; Hagemann, H.; Embs, J.P.; D’Anna, V.; Černý, R. Di-hydrogen contact induced lattice instabilities and structural dynamics in complex hydride perovskites. J. Phys. Condens. Matter 2015, 27, 265403. [CrossRef] [PubMed]

126. Černý, R.; Schouwink, P.; Sadikin, Y.; Stare, K.; Smrčok, L.; Richter, B.; Jensen, T.R. Trimetallic Borohydride $\mathrm{Li}_{3} \mathrm{MZn}_{5}\left(\mathrm{BH}_{4}\right)_{15}(\mathrm{M}=\mathrm{Mg}, \mathrm{Mn})$ Containing Two Weakly Interconnected Frameworks. Inorg. Chem. 2013, 52, 9941-9947. [CrossRef] [PubMed]

127. Schouwink, P.; Ley, M.B.; Jensen, T.R.; Černý, R. Borohydrides: From sheet to framework topologies. Dalton Trans. 2014, 43, 7726-7733. [CrossRef] [PubMed]

128. Brighi, M.; Schouwink, P.; Sadikin, Y.; Černý, R. Fast ion conduction in garnet-type metal borohydrides $\mathrm{Li}_{3} \mathrm{~K}_{3} \mathrm{Ce}_{2}\left(\mathrm{BH}_{4}\right)_{12}$ and $\mathrm{Li}_{3} \mathrm{~K}_{3} \mathrm{La}_{2}\left(\mathrm{BH}_{4}\right)_{12}$. J. Alloys Compd. 2016, 662, 388-395. [CrossRef]

129. Payandeh GharibDoust, S.; Heere, M.; Sørby, M.H.; Ley, M.B.; Ravnsbæk, D.B.; Hauback, B.C.; Černý, R.; Jensen, T.R. Synthesis, structure and properties of new bimetallic sodium and potassium lanthanum borohydrides. Dalton Trans. 2016, 45, 19002-19011. [CrossRef] [PubMed]

130. Jepsen, L.H.; Ley, M.B.; Filinchuk, Y.; Besenbacher, F.; Jensen, T.R. Tailoring the Properties of Ammine Metal Borohydrides for Solid-State Hydrogen Storage. ChemSusChem 2015, 8, 1452-1463. [CrossRef] [PubMed]

131. Huang, J.; Tan, Y.; Su, J.; Gu, Q.; Černý, R.; Ouyang, L.; Sun, D.; Yu, X.; Zhu, M. Synthesis, structure and dehydrogenation of zirconium borohydride octaammoniate. Chem. Commun. 2015, 51, 2794-2797. [CrossRef] [PubMed]

132. Jepsen, L.H.; Ley, M.B.; Černý, R.; Lee, Y.-S.; Cho, Y.W.; Ravnsbæk, D.; Besenbacher, F.; Skibsted, J.; Jensen, T.R. Trends in Syntheses, Structures, and Properties for Three Series of Ammine Rare-Earth Metal Borohydrides, $\mathrm{M}\left(\mathrm{BH}_{4}\right)_{3} \cdot \mathrm{nNH}_{3}(\mathrm{M}=\mathrm{Y}, \mathrm{Gd}$, and Dy). Inorg. Chem. 2015, 54, 7402-7414. [CrossRef] [PubMed]

133. Guo, Y.; Yu, X.; Sun, W.; Sun, D.; Yang, W. The Hydrogen-Enriched Al-B-N System as an Advanced Solid Hydrogen-Storage Candidate. Angew. Chem. Int. Ed. 2011, 50, 1087-1091. [CrossRef] [PubMed]

134. Guo, Y.; Wu, H.; Zhou, W.; Yu, X. Dehydrogenation Tuning of Ammine Borohydrides Using Double-Metal Cations. J. Am. Chem. Soc. 2011, 133, 4690-4693. [CrossRef] [PubMed]

135. Gu, Q.; Gao, L.; Guo, Y.; Tan, Y.; Tang, Z.; Wallwork, K.S.; Zhang, F.; Yu, X. Structure and decomposition of zinc borohydride ammonia adduct: Towards a pure hydrogen release. Energy Environ. Sci. 2012, 5, 7590-7600. [CrossRef]

136. Jepsen, L.H.; Lee, Y.-S.; Černý, R.; Sarusie, R.S.; Cho, Y.W.; Besenbacher, F.; Jensen, T.R. Ammine Calcium and Strontium Borohydrides: Syntheses, Structures, and Properties. ChemSusChem 2015, 8, 3472-3482. [CrossRef] [PubMed]

137. Guo, Y.; Jiang, Y.; Xia, G.; Yu, X. Ammine aluminium borohydrides: An appealing system releasing over $12 \mathrm{wt} \%$ pure $\mathrm{H}_{2}$ under moderate temperature. Chem. Commun. 2012, 48, 4408-4410. [CrossRef] [PubMed]

138. Wu, H.; Zhou, W.; Pinkerton, F.E.; Meyer, M.S.; Srinivas, G.; Yildirim, T.; Udovic, T.J.; Rush, J.J. A new family of metal borohydride ammonia borane complexes: Synthesis, structures, and hydrogen storage properties. J. Mater. Chem. 2010, 20, 6550-6556. [CrossRef]

139. Jepsen, L.H.; Ban, V.; Møller, K.T.; Lee, Y.-S.; Cho, Y.W.; Besenbacher, F.; Filinchuk, Y.; Skibsted, J.; Jensen, T.R. Synthesis, Crystal Structure, Thermal Decomposition, and 11B MAS NMR Characterization of $\mathrm{Mg}\left(\mathrm{BH}_{4}\right)_{2}\left(\mathrm{NH}_{3} \mathrm{BH}_{3}\right)_{2}$. J. Phys. Chem. C 2014, 118, 12141-12153. [CrossRef]

140. Dovgaliuk, I.; Le Duff, C.S.; Robeyns, K.; Devillers, M.; Filinchuk, Y. Mild Dehydrogenation of Ammonia Borane Complexed with Aluminum Borohydride. Chem. Mater. 2015, 27, 768-777. [CrossRef]

141. Luo, J.; Wu, H.; Zhou, W.; Kang, X.; Fang, Z.; Wang, $\mathrm{P}$. $\mathrm{LiBH}_{4} \cdot \mathrm{NH}_{3} \mathrm{BH}_{3}$ : A new lithium borohydride ammonia borane compound with a novel structure and favorable hydrogen storage properties. Int. J. Hydrogen Energy 2012, 37, 10750-10757. [CrossRef] 
142. Chen, X.; Yuan, F.; Gu, Q.; Yu, X. Synthesis, structures and hydrogen storage properties of two new H-enriched compounds: $\mathrm{Mg}\left(\mathrm{BH}_{4}\right)_{2}\left(\mathrm{NH}_{3} \mathrm{BH}_{3}\right)_{2}$ and $\mathrm{Mg}\left(\mathrm{BH}_{4}\right)_{2} \cdot\left(\mathrm{NH}_{3}\right)_{2}\left(\mathrm{NH}_{3} \mathrm{BH}_{3}\right)$. Dalton Trans. 2013, 42, 14365-14368. [CrossRef] [PubMed]

143. Chua, Y.S.; Chen, P.; Wu, G.; Xiong, Z. Development of amidoboranes for hydrogen storage. Chem. Commun. 2011, 47, 5116-5129. [CrossRef] [PubMed]

144. Dovgaliuk, I.; Jepsen, L.H.; Safin, D.A.; Łodziana, Z.; Dyadkin, V.; Jensen, T.R.; Devillers, M.; Filinchuk, Y. A Composite of Complex and Chemical Hydrides Yields the First Al-Based Amidoborane with Improved Hydrogen Storage Properties. Chem. Eur. J. 2015, 14562-14570. [CrossRef] [PubMed]

145. Møller, K.T.; Jørgensen, M.; Andreasen, J.G.; Skibsted, J.; Łodziana, Z.; Filinchuk, Y.; Jensen, T.R. Synthesis and Thermal Decomposition of Potassium Tetraamidoboranealuminate, $\mathrm{K}\left[\mathrm{Al}\left(\mathrm{NH}_{2} \mathrm{BH}_{3}\right)_{4}\right]$. Int. J. Hydrogen Energy 2017. accepted.

146. Ikoma, M. Ni-Metal Hydride Batteries. In Encyclopedia of Applied Electrochemistry; Kreysa, G., Ota, K., Savinell, R.F., Eds.; Springer: New York, NY, USA, 2014; pp. 1363-1366. ISBN 978-1-4419-6995-8.

147. Sakai, T.; Miyamura, H.; Kuriyama, N.; Kato, A.; Oguro, K.; Ishikawa, H. Metal Hydride Anodes for Nickel-Hydrogen Secondary Battery. J. Electrochem. Soc. 1990, 137, 795-799. [CrossRef]

148. Møller, K.T.; Jensen, T.R.; Akiba, E.; Li, H. Hydrogen-A sustainable energy carrier. Prog. Nat. Sci. Mater. Int. 2017, 27, 34-40. [CrossRef]

149. Oumellal, Y.; Rougier, A.; Nazri, G.A.; Tarascon, J.-M.; Aymard, L. Metal hydrides for lithium-ion batteries. Nat. Mater. 2008, 7, 916-921. [CrossRef] [PubMed]

150. Zaïdi, W.; Oumellal, Y.; Bonnet, J.-P.; Zhang, J.; Cuevas, F.; Latroche, M.; Bobet, J.-L.; Aymard, L. Carboxymethylcellulose and carboxymethylcellulose-formate as binders in $\mathrm{MgH}_{2}$-carbon composites negative electrode for lithium-ion batteries. J. Power Sources 2011, 196, 2854-2857. [CrossRef]

151. Hanada, N.; Kamura, A.; Suzuki, H.; Takai, K.; Ichikawa, T.; Kojima, Y. Electrochemical charge and discharge properties for the formation of magnesium and aluminum hydrides. J. Alloys Compd. 2011, 509, S584-S587. [CrossRef]

152. Brutti, S.; Mulas, G.; Piciollo, E.; Panero, S.; Reale, P. Magnesium hydride as a high capacity negative electrode for lithium ion batteries. J. Mater. Chem. 2012, 22, 14531-14537. [CrossRef]

153. Ikeda, S.; Ichikawa, T.; Kawahito, K.; Hirabayashi, K.; Miyaoka, H.; Kojima, Y. Anode properties of magnesium hydride catalyzed with niobium oxide for an all solid-state lithium-ion battery. Chem. Commun. 2013, 49, 7174-7176. [CrossRef] [PubMed]

154. Oumellal, Y.; Zlotea, C.; Bastide, S.; Cachet-Vivier, C.; Léonel, E.; Sengmany, S.; Leroy, E.; Aymard, L.; Bonnet, J.-P.; Latroche, M. Bottom-up preparation of $\mathrm{MgH}_{2}$ nanoparticles with enhanced cycle life stability during electrochemical conversion in Li-ion batteries. Nanoscale 2014, 6, 14459-14466. [CrossRef] [PubMed]

155. Ikeda, S.; Ichikawa, T.; Goshome, K.; Yamaguchi, S.; Miyaoka, H.; Kojima, Y. Anode properties of $\mathrm{Al}_{2} \mathrm{O}_{3}$-added $\mathrm{MgH}_{2}$ for all-solid-state lithium-ion batteries. J. Solid State Electrochem. 2015, 12, 3639-3644. [CrossRef]

156. Meggiolaro, D.; Gigli, G.; Paolone, A.; Reale, P.; Doublet, M.L.; Brutti, S. Origin of the Voltage Hysteresis of $\mathrm{MgH}_{2}$ Electrodes in Lithium Batteries. J. Phys. Chem. C 2015, 119, 17044-17052. [CrossRef]

157. Zeng, L.; Ichikawa, T.; Kawahito, K.; Miyaoka, H.; Kojima, Y. Bulk-Type All-Solid-State Lithium-Ion Batteries: Remarkable Performances of a Carbon Nanofiber-Supported $\mathrm{MgH}_{2}$ Composite Electrode. ACS Appl. Mater. Interfaces 2017, 9, 2261-2266. [CrossRef] [PubMed]

158. Peng, X.; Wang, H.; Hu, R.; Ouyang, L.; Liu, J.; Zhu, M. Electrochemical performances of $\mathrm{MgH}_{2}$ and $\mathrm{MgH}_{2}-\mathrm{C}$ films for lithium ion battery anode. J. Alloys Compd. 2017, 711, 473-479. [CrossRef]

159. Oumellal, Y.; Zaïdi, W.; Bonnet, J.-P.; Cuevas, F.; Latroche, M.; Zhang, J.; Bobet, J.-L.; Rougier, A.; Aymard, L. Reactivity of $\mathrm{TiH}_{2}$ hydride with lithium ion: Evidence for a new conversion mechanism. Int. J. Hydrogen Energy 2012, 37, 7831-7835. [CrossRef]

160. Kawahito, K.; Zeng, L.; Ichikawa, T.; Miyaoka, H.; Kojima, Y. Electrochemical Performance of Titanium Hydride for Bulk-Type All-Solid-State Lithium-Ion Batteries. Mater. Trans. 2016, 57, 755-757. [CrossRef]

161. Teprovich, J.A.; Zhang, J.; Colón-Mercado, H.; Cuevas, F.; Peters, B.; Greenway, S.; Zidan, R.; Latroche, M. Li-Driven Electrochemical Conversion Reaction of $\mathrm{AlH}_{3}, \mathrm{LiAlH}_{4}$, and $\mathrm{NaAlH}_{4}$. J. Phys. Chem. C 2015, 119, 4666-4674. [CrossRef]

162. Oumellal, Y.; Rougier, A.; Tarascon, J.-M.; Aymard, L. $2 \mathrm{LiH}+\mathrm{M}(\mathrm{M}=\mathrm{Mg}$, Ti): New concept of negative electrode for rechargeable lithium-ion batteries. J. Power Sources 2009, 192, 698-702. [CrossRef] 
163. Huang, L.; Aymard, L.; Bonnet, J.-P. $\mathrm{MgH}_{2}-\mathrm{TiH}_{2}$ mixture as an anode for lithium-ion batteries: Synergic enhancement of the conversion electrode electrochemical performance. J. Mater. Chem. A 2015, 3, 15091-15096. [CrossRef]

164. Zaïdi, W.; Bonnet, J.-P.; Zhang, J.; Cuevas, F.; Latroche, M.; Couillaud, S.; Bobet, J.-L.; Sougrati, M.T.; Jumas, J.-C.; Aymard, L. Reactivity of complex hydrides $\mathrm{Mg}_{2} \mathrm{FeH}_{6}, \mathrm{Mg}_{2} \mathrm{CoH}_{5}$ and $\mathrm{Mg}_{2} \mathrm{NiH}_{4}$ with lithium ion: Far from equilibrium electrochemically driven conversion reactions. Int. J. Hydrogen Energy 2013, 38, 4798-4808. [CrossRef]

165. Aymard, L.; Oumellal, Y.; Bonnet, J.-P. Metal hydrides: An innovative and challenging conversion reaction anode for lithium-ion batteries. Beilstein J. Nanotechnol. 2015, 6, 1821-1839. [CrossRef] [PubMed]

166. Sartori, S.; Cuevas, F.; Latroche, M. Metal hydrides used as negative electrode materials for Li-ion batteries. Appl. Phys. A 2016, 2, 1-7. [CrossRef]

167. Silvestri, L.; Forgia, S.; Farina, L.; Meggiolaro, D.; Panero, S.; La Barbera, A.; Brutti, S.; Reale, P. Lithium Alanates as Negative Electrodes in Lithium-Ion Batteries. ChemElectroChem 2015, 2, 877-886. [CrossRef]

168. Silvestri, L.; Farina, L.; Meggiolaro, D.; Panero, S.; Padella, F.; Brutti, S.; Reale, P. Reactivity of Sodium Alanates in Lithium Batteries. J. Phys. Chem. C 2015, 119, 28766-28775. [CrossRef]

169. Cirrincione, L.; Silvestri, L.; Mallia, C.; Stallworth, P.E.; Greenbaum, S.; Brutti, S.; Panero, S.; Reale, P. Investigation of the Effects of Mechanochemical Treatment on $\mathrm{NaAlH}_{4}$ Based Anode Materials for Li-Ion Batteries. J. Electrochem. Soc. 2016, 163, A2628-A2635. [CrossRef]

170. Silvestri, L.; Paolone, A.; Cirrincione, L.; Stallworth, P.; Greenbaum, S.; Panero, S.; Brutti, S.; Reale, P. NaAlH Nanoconfinement in a Mesoporous Carbon for Application in Lithium Ion Batteries. J. Electrochem. Soc. 2017, 164, A1120-A1125. [CrossRef]

171. Huen, P.; Peru, F.; Charalambopoulou, G.; Steriotis, T.A.; Jensen, T.R.; Ravnsbæk, D.B. Nanoconfined NaAlH4 Conversion Electrodes for Li Batteries. ACS Omega 2017, 2, 1956-1967. [CrossRef]

172. Meggiolaro, D.; Farina, L.; Silvestri, L.; Panero, S.; Brutti, S.; Reale, P. Lightweight Borohydrides Electro-Activity in Lithium Cells. Energies 2016, 9, 238. [CrossRef]

173. Mason, T.H.; Liu, X.; Hong, J.; Graetz, J.; Majzoub, E.H. First-Principles Study of Novel Conversion Reactions for High-Capacity Li-Ion Battery Anodes in the Li-Mg-B-N-H System. J. Phys. Chem. C 2011, 115, 16681-16687. [CrossRef]

174. Unemoto, A.; Matsuo, M.; Orimo, S. Complex Hydrides for Electrochemical Energy Storage. Adv. Funct. Mater. 2014, 24, 2267-2279. [CrossRef]

175. Matsuo, M.; Orimo, S. Lithium Fast-Ionic Conduction in Complex Hydrides: Review and Prospects. Adv. Energy Mater. 2011, 1, 161-172. [CrossRef]

176. De Jongh, P.E.; Blanchard, D.; Matsuo, M.; Udovic, T.J.; Orimo, S. Complex hydrides as room-temperature solid electrolytes for rechargeable batteries. Appl. Phys. A 2016, 122, 251. [CrossRef]

177. Matsuo, M.; Nakamori, Y.; Orimo, S.; Maekawa, H.; Takamura, H. Lithium superionic conduction in lithium borohydride accompanied by structural transition. Appl. Phys. Lett. 2007, 91, 224103. [CrossRef]

178. Maekawa, H.; Matsuo, M.; Takamura, H.; Ando, M.; Noda, Y.; Karahashi, T.; Orimo, S. Halide-Stabilized LiBH4, a Room-Temperature Lithium Fast-Ion Conductor. J. Am. Chem. Soc. 2009, 131, 894-895. [CrossRef] [PubMed]

179. Rude, L.H.; Groppo, E.; Arnbjerg, L.M.; Ravnsbæk, D.B.; Malmkjær, R.A.; Filinchuk, Y.; Baricco, M.; Besenbacher, F.; Jensen, T.R. Iodide substitution in lithium borohydride, $\mathrm{LiBH}_{4}$-LiI. J. Alloys Compd. 2011, 509, 8299-8305. [CrossRef]

180. Mosegaard, L.; Møller, B.; Jørgensen, J.-E.; Filinchuk, Y.; Cerenius, Y.; Hanson, J.C.; Dimasi, E.; Besenbacher, F.; Jensen, T.R. Reactivity of $\mathrm{LiBH}_{4}$ : In Situ Synchrotron Radiation Powder X-ray Diffraction Study. J. Phys. Chem. C 2008, 112, 1299-1303. [CrossRef]

181. Mohtadi, R.; Matsui, M.; Arthur, T.S.; Hwang, S.-J. Magnesium Borohydride: From Hydrogen Storage to Magnesium Battery. Angew. Chem. Int. Ed. 2012, 51, 9780-9783. [CrossRef] [PubMed]

182. Roedern, E.; Kühnel, R.-S.; Remhof, A.; Battaglia, C. Magnesium Ethylenediamine Borohydride as Solid-State Electrolyte for Magnesium Batteries. Sci. Rep. 2017, 7, 46189. [CrossRef] [PubMed]

183. Higashi, S.; Miwa, K.; Aoki, M.; Takechi, K. A novel inorganic solid state ion conductor for rechargeable $\mathrm{Mg}$ batteries. Chem. Commun. 2014, 50, 1320-1322. [CrossRef] [PubMed] 
184. Udovic, T.J.; Matsuo, M.; Tang, W.S.; Wu, H.; Stavila, V.; Soloninin, A.V.; Skoryunov, R.V.; Babanova, O.A.; Skripov, A.V.; Rush, J.J.; et al. Exceptional Superionic Conductivity in Disordered Sodium Decahydro-closo-decaborate. Adv. Mater. 2014, 26, 7622-7626. [CrossRef] [PubMed]

185. Udovic, T.J.; Matsuo, M.; Unemoto, A.; Verdal, N.; Stavila, V.; Skripov, A.V.; Rush, J.J.; Takamura, H.; Orimo, S. Sodium superionic conduction in $\mathrm{Na}_{2} \mathrm{~B}_{12} \mathrm{H}_{12}$. Chem. Commun. 2014, 50, 3750. [CrossRef] [PubMed]

186. Ravnsbæk, D.B.; Sørensen, L.H.; Filinchuk, Y.; Reed, D.; Book, D.; Jakobsen, H.J.; Besenbacher, F.; Skibsted, J.; Jensen, T.R. Mixed-Anion and Mixed-Cation Borohydride $\mathrm{KZn}\left(\mathrm{BH}_{4}\right) \mathrm{Cl}_{2}$ : Synthesis, Structure and Thermal Decomposition. Eur. J. Inorg. Chem. 2010, 2010, 1608-1612. [CrossRef]

187. Ravnsbæk, D.B.; Ley, M.B.; Lee, Y.-S.; Hagemann, H.; D'Anna, V.; Cho, Y.W.; Filinchuk, Y.; Jensen, T.R. A mixed-cation mixed-anion borohydride $\mathrm{NaY}\left(\mathrm{BH}_{4}\right)_{2} \mathrm{Cl}_{2}$. Int. J. Hydrogen Energy 2012, 37, 8428-8438. [CrossRef]

188. Jaron, T.; Grochala, W. Probing Lewis acidity of $\mathrm{Y}\left(\mathrm{BH}_{4}\right)_{3}$ via its reactions with $\mathrm{MBH} 4(\mathrm{M}=\mathrm{Li}, \mathrm{Na}, \mathrm{K}, \mathrm{NMe})_{4}$. Dalton Trans. 2011, 40, 12808-12817. [CrossRef] [PubMed]

189. Černý, R.; Ravnsbæk, D.B.; Schouwink, P.; Filinchuk, Y.; Penin, N.; Teyssier, J.; Smrčok, L'; Jensen, T.R. Potassium Zinc Borohydrides Containing Triangular $\left[\mathrm{Zn}\left(\mathrm{BH}_{4}\right)_{3}\right]^{-}$and Tetrahedral $\left[\mathrm{Zn}_{(}\left(\mathrm{BH}_{4}\right)_{\mathrm{x}} \mathrm{Cl}_{4-\mathrm{x}}\right]_{2}{ }^{-}$ Anions. J. Phys. Chem. C 2012, 116, 1563-1571. [CrossRef]

190. Rude, L.H.; Filsø, U.; D’Anna, V.; Spyratou, A.; Richter, B.; Hino, S.; Zavorotynska, O.; Baricco, M.; Sørby, M.H.; Hauback, B.C.; et al. Hydrogen-fluorine exchange in $\mathrm{NaBH}_{4}-\mathrm{NaBF}_{4}$. Phys. Chem. Chem. Phys. 2013, 15, 18185-18194. [CrossRef] [PubMed]

191. Richter, B.; Ravnsbæk, D.B.; Sharma, M.; Spyratou, A.; Hagemann, H.; Jensen, T.R. Fluoride substitution in $\mathrm{LiBH}_{4}$ : Destabilization and decomposition. Phys. Chem. Chem. Phys. 2017, in press. [CrossRef]

192. Ley, M.B.; Boulineau, S.; Janot, R.; Filinchuk, Y.; Jensen, T.R. New Li Ion Conductors and Solid State Hydrogen Storage Materials: $\mathrm{LiM}\left(\mathrm{BH}_{4}\right)_{3} \mathrm{Cl}, \mathrm{M}=\mathrm{La}, \mathrm{Gd}$. J. Phys. Chem. C 2012, 116, 21267-21276. [CrossRef]

193. Frommen, C.; Sørby, M.H.; Ravindran, P.; Vajeeston, P.; Fjellvåg, H.; Hauback, B.C. Synthesis, Crystal Structure, and Thermal Properties of the First Mixed-Metal and Anion-Substituted Rare Earth Borohydride $\mathrm{LiCe}\left(\mathrm{BH}_{4}\right)_{3} \mathrm{Cl}$. J. Phys. Chem. C 2011, 115, 23591-23602. [CrossRef]

194. Olsen, J.E.; Frommen, C.; Jensen, T.R.; Riktor, M.D.; Sørby, M.H.; Hauback, B.C. Structure and thermal properties of composites with RE-borohydrides ( $\mathrm{RE}=\mathrm{La}, \mathrm{Ce}, \mathrm{Pr}, \mathrm{Nd}, \mathrm{Sm}, \mathrm{Eu}, \mathrm{Gd}, \mathrm{Tb}, \mathrm{Er}, \mathrm{Yb}$ or Lu) and $\mathrm{LiBH}_{4}$. RSC Adv. 2013, 4, 1570-1582. [CrossRef]

195. Skripov, A.V.; Soloninin, A.V.; Ley, M.B.; Jensen, T.R.; Filinchuk, Y. Nuclear Magnetic Resonance Studies of $\mathrm{BH}_{4}$ Reorientations and Li Diffusion in LiLa $\left(\mathrm{BH}_{4}\right)_{3} \mathrm{Cl}$. J. Phys. Chem. C 2013, 117, 14965-14972. [CrossRef]

196. Lundén, A. On the Paddle -Wheel Mechanism for Cation Conduction in Lithium Sulphate. Z. Naturforschung A 2014, 50, 1067-1076. [CrossRef]

197. Payandeh GharibDoust, S.; Brighi, M.; Sadikin, Y.; Ravnsbæk, D.B.; Černý, R.; Skibsted, J.; Jensen, T.R. Synthesis, Structure, and Li-Ion Conductivity of $\mathrm{LiLa}\left(\mathrm{BH}_{4}\right)_{3} \mathrm{X}, \mathrm{X}=\mathrm{Cl}, \mathrm{Br}$, I. J. Phys. Chem. C 2017, 121, 19010-19021. [CrossRef]

198. Lee, Y.-S.; Ley, M.B.; Jensen, T.R.; Cho, Y.W. Lithium Ion Disorder and Conduction Mechanism in $\mathrm{LiCe}\left(\mathrm{BH}_{4}\right)_{3} \mathrm{Cl}$. J. Phys. Chem. C 2016, 120, 19035-19042. [CrossRef]

199. Lee, Y.-S.; Filinchuk, Y.; Lee, H.-S.; Suh, J.-Y.; Kim, J.W.; Yu, J.-S.; Cho, Y.W. On the Formation and the Structure of the First Bimetallic Borohydride Borate, $\mathrm{LiCa}_{3}\left(\mathrm{BH}_{4}\right)\left(\mathrm{BO}_{3}\right)_{2}$. J. Phys. Chem. C 2011, 115, 10298-10304. [CrossRef]

200. Riktor, M.D.; Filinchuk, Y.; Vajeeston, P.; Bardají, E.G.; Fichtner, M.; Fjellvåg, H.; Sørby, M.H.; Hauback, B.C. The crystal structure of the first borohydride borate, $\mathrm{Ca}_{3}\left(\mathrm{BD}_{4}\right)_{3}\left(\mathrm{BO}_{3}\right)$. J. Mater. Chem. 2011, $21,7188$. [CrossRef]

201. Paskevicius, M.; Hansen, B.R.S.; Jørgensen, M.; Richter, B.; Jensen, T.R. Multifunctionality of Silver closo-Boranes. Nat. Commun. 2017. [CrossRef] [PubMed]

202. Hansen, B.R.S.; Paskevicius, M.; Jørgensen, M.; Jensen, T.R. Halogenated Sodium-closo-Dodecaboranes as Solid-State Ion Conductors. Chem. Mater. 2017, 29, 3423-3430. [CrossRef]

203. Bukovsky, E.V.; Peryshkov, D.V.; Wu, H.; Zhou, W.; Tang, W.S.; Jones, W.M.; Stavila, V.; Udovic, T.J.; Strauss, S.H. Comparison of the Coordination of $\mathrm{B}_{12} \mathrm{~F}_{12}{ }^{2-}, \mathrm{B}_{12} \mathrm{Cl}_{12}{ }^{2-}$, and $\mathrm{B}_{12} \mathrm{H}_{12}{ }^{2-}$ to $\mathrm{Na}^{+}$in the Solid State: Crystal Structures and Thermal Behavior of $\mathrm{Na}_{2}\left(\mathrm{~B}_{12} \mathrm{~F}_{12}\right), \mathrm{Na}_{2}\left(\mathrm{H}_{2} \mathrm{O}\right)_{4}\left(\mathrm{~B}_{12} \mathrm{~F}_{12}\right), \mathrm{Na}_{2}\left(\mathrm{~B}_{12} \mathrm{Cl}_{12}\right)$, and $\mathrm{Na}_{2}\left(\mathrm{H}_{2} \mathrm{O}\right)_{6}\left(\mathrm{~B}_{12} \mathrm{Cl}_{12}\right)$. Inorg. Chem. 2017, 56, 4369-4379. [CrossRef] [PubMed] 
204. Tang, W.S.; Unemoto, A.; Zhou, W.; Stavila, V.; Matsuo, M.; Wu, H.; Orimo, S.; Udovic, T.J. Unparalleled lithium and sodium superionic conduction in solid electrolytes with large monovalent cage-like anions. Energy Environ. Sci. 2015, 8, 3637-3645. [CrossRef] [PubMed]

205. Sandrock, G.; Thomas, G. The IEA/DOE/SNL on-line hydride databases. Appl. Phys. A 2001, 72, $153-155$. [CrossRef]

206. Johnson, J.R. Reaction of hydrogen with the high temperature $\left(\mathrm{C}_{14}\right)$ form of $\mathrm{TiCr}_{2}$. J. Common Met. 1980, 73, 345-354. [CrossRef]

207. Manchester, F.D. Phase Diagrams of Binary Hydrogen Alloys; Monograph Series on Alloy Phase Diagrams, 13; ASM International: Materials Park, OH, USA, 2000; ISBN 0-87170-587-7.

208. Sandrock, G.; Suda, S.; Schlapbach, L. Hydrogen in Intermetallic Compounds II, Topics in Applied Physics; Springer: Berlin/Heidelberg, Germany, 1992; Volume 67.

209. Dantzer, P. Properties of intermetallic compounds suitable for hydrogen storage applications. Mater. Sci. Eng. A 2002, 329-331, 313-320. [CrossRef]

210. Sandrock, G.; Bowman, R.C. Gas-based hydride applications: Recent progress and future needs. J. Alloys Compd. 2003, 356, 794-799. [CrossRef]

211. Lototskyy, M.V.; Yartys, V.A.; Pollet, B.G.; Bowman, R.C., Jr. Metal hydride hydrogen compressors: A review. Int. J. Hydrogen Energy 2014, 39, 5818-5851. [CrossRef]

212. SunShot Vision Study. Chapter 5: Concentrating Solar Power: Technologies, Cost, and Performance; US Department of Energy: Washington, DC, USA, 2012.

213. Rönnebro, E.C.E.; Whyatt, G.; Powell, M.; Westman, M.; Zheng, F.; Fang, Z.Z. Metal Hydrides for High-Temperature Power Generation. Energies 2015, 8, 8406-8430. [CrossRef]

214. Sheppard, D.A.; Paskevicius, M.; Humphries, T.D.; Felderhoff, M.; Capurso, G.; von Colbe, J.B.; Dornheim, M.; Klassen, T.; Ward, P.A.; Teprovich, J.A.; et al. Metal hydrides for concentrating solar thermal power energy storage. Appl. Phys. A 2016, 122, 395. [CrossRef]

215. Sheppard, D.A.; Humphries, T.D.; Buckley, C.E. Sodium-based hydrides for thermal energy applications. Appl. Phys. A 2016, 122, 406. [CrossRef]

216. Fellet, M.; Buckley, C.E.; Paskevicius, M.; Sheppard, D.A. Research on metal hydrides revived for next-generation solutions to renewable energy storage. MRS Bull. 2013, 38, 1012-1013. [CrossRef]

217. Ward, P.A.; Corgnale, C.; Teprovich, J.A.; Motyka, T.; Hardy, B.; Sheppard, D.; Buckley, C.; Zidan, R. Technical challenges and future direction for high-efficiency metal hydride thermal energy storage systems. Appl. Phys. A 2016, 122, 462. [CrossRef]

218. Pardo, P.; Deydier, A.; Anxionnaz-Minvielle, Z.; Rougé, S.; Cabassud, M.; Cognet, P. A review on high temperature thermochemical heat energy storage. Renew. Sustain. Energy Rev. 2014, 32, 591-610. [CrossRef]

219. Corgnale, C.; Hardy, B.; Motyka, T.; Zidan, R.; Teprovich, J.; Peters, B. Screening analysis of metal hydride based thermal energy storage systems for concentrating solar power plants. Renew. Sustain. Energy Rev. 2014, 38, 821-833. [CrossRef]

220. Harries, D.N.; Paskevicius, M.; Sheppard, D.A.; Price, T.E.C.; Buckley, C.E. Concentrating Solar Thermal Heat Storage Using Metal Hydrides. Proc. IEEE 2012, 100, 539-549. [CrossRef]

221. Sheppard, D.A.; Humphries, T.D.; Buckley, C.E. What is old is new again. Mater. Today 2015, 8, $414-415$. [CrossRef]

222. Felderhoff, M.; Urbanczyk, R.; Peil, S. Thermochemical heat storage for high temperature applications-A review. Green 2013, 3, 113-123. [CrossRef]

223. Paskevicius, M.; Sheppard, D.A.; Williamson, K.; Buckley, C.E. Metal hydride thermal heat storage prototype for concentrating solar thermal power. Energy 2015, 88, 469-477. [CrossRef]

224. Bogdanović, B.; Spliethoff, B.; Ritter, A. The magnesium hydride system for heat storage and cooling. Z. Phys. Chem. 1989, 164, 1497-1508. [CrossRef]

225. Groll, M.; Isselhorst, A.; Wierse, M. Metal hydride devices for environmentally clean energy technology. Int. J. Hydrogen Energy 1994, 19, 507-515. [CrossRef]

226. Bogdanović, B.; Ritter, A.; Spliethoff, B.; Straßburger, K. A process steam generator based on the high temperature magnesium hydride/magnesium heat storage system. Int. J. Hydrogen Energy 1995, 20, 811-822. [CrossRef] 
227. Dong, D.; Humphries, T.D.; Sheppard, D.A.; Stansby, B.; Paskevicius, M.; Sofianos, M.V.; Chaudhary, A.-L.; Dornheim, M.; Buckley, C.E. Thermal optimisation of metal hydride reactors for thermal energy storage applications. Sustain. Energy Fuels 2017. [CrossRef]

228. Humphries, T.D.; Sheppard, D.A.; Rowles, M.R.; Sofianos, M.V.; Buckley, C.E. Fluoride substitution in sodium hydride for thermal energy storage applications. J. Mater. Chem. A 2016, 4, 12170-12178. [CrossRef]

229. Sheppard, D.A.; Paskevicius, M.; Buckley, C.E. Thermodynamics of Hydrogen Desorption from $\mathrm{NaMgH}_{3}$ and Its Application as a Solar Heat Storage Medium. Chem. Mater. 2011, 23, 4298-4300. [CrossRef]

230. Sheppard, D.A.; Corgnale, C.; Hardy, B.; Motyka, T.; Zidan, R.; Paskevicius, M.; Buckley, C.E. Hydriding characteristics of $\mathrm{NaMgH}_{2} \mathrm{~F}$ with preliminary technical and cost evaluation of magnesium-based metal hydride materials for concentrating solar power thermal storage. RSC Adv. 2014, 4, 26552-26562. [CrossRef]

231. Javadian, P.; Sheppard, D.A.; Jensen, T.R.; Buckley, C.E. Destabilization of lithium hydride and the thermodynamic assessment of the $\mathrm{Li}-\mathrm{Al}-\mathrm{H}$ system for solar thermal energy storage. Rsc Adv. 2016, 6, 94927-94933. [CrossRef]

232. Doi, K.; Hino, S.; Miyaoka, H.; Ichikawa, T.; Kojima, Y. Hydrogen storage properties of lithium silicon alloy synthesized by mechanical alloying. J. Power Sources 2011, 196, 504-507. [CrossRef]

233. Vajo, J.J.; Mertens, F.; Ahn, C.C.; Robert, C.B.; Fultz, B. Altering Hydrogen Storage Properties by Hydride Destabilization through Alloy Formation: $\mathrm{LiH}$ and $\mathrm{MgH}_{2}$ Destabilized with Si. J. Phys. Chem. B 2004, 108, 13977-13983. [CrossRef]

234. Veleckis, E. Application of the hydrogen titration method to a thermodynamic investigation of solid Al-Ca alloys. J. Common Met. 1981, 80, 241-255. [CrossRef]

235. Reilly, J.J.; Wiswall, R.H. Reaction of hydrogen with alloys of magnesium and nickel and the formation of Mg2NiH4. Inorg. Chem. 1968, 7, 2254-2256. [CrossRef]

236. Reiser, A.; Bogdanović, B.; Schlichte, K. The application of Mg-based metal-hydrides as heat energy storage systems. Int. J. Hydrogen Energy 2000, 25, 425-430. [CrossRef]

237. Bogdanović, B.; Reiser, A.; Schlichte, K.; Spliethoff, B.; Tesche, B. Thermodynamics and dynamics of the $\mathrm{Mg}-\mathrm{Fe}-\mathrm{H}$ system and its potential for thermochemical thermal energy storage. J. Alloys Compd. 2002, 345, 77-89. [CrossRef]

238. Nguyen, T.T.; Sheppard, D.A.; Buckley, C.E. Lithium imide systems for high temperature heat storage in concentrated solar thermal systems. J. Alloys Compd. 2017, 716, 291-298. [CrossRef]

239. Li, Y.; Li, P.; Qu, X. Investigation on $\mathrm{LiBH}_{4}-\mathrm{CaH}_{2}$ composite and its potential for thermal energy storage. Sci. Rep. 2017, 7, 41754. [CrossRef] [PubMed]

240. El Kharbachi, A.; Pinatel, E.; Nuta, I.; Baricco, M. A thermodynamic assessment of LiBH4. Calphad 2012, 39, 80-90. [CrossRef]

241. HSC Chemistry, version 6.12; Outotec Research Oy: Pori, Finland, 2006.

242. Javadian, P.; GharibDoust, S.P.; Li, H.-W.; Sheppard, D.A.; Buckley, C.E.; Jensen, T.R. Reversibility of LiBH 4 Facilitated by the $\mathrm{LiBH}_{4}-\mathrm{Ca}\left(\mathrm{BH}_{4}\right)_{2}$ Eutectic. J. Phys. Chem. C 2017. [CrossRef]

243. Bogdanović, B.; Brand, R.A.; Marjanović, A.; Schwickardi, M.; Tölle, J. Metal-doped sodium aluminium hydrides as potential new hydrogen storage materials. J. Alloys Compd. 2000, 302, 36-58. [CrossRef]

244. Fossdal, A.; Brinks, H.W.; Fonneløp, J.E.; Hauback, B.C. Pressure-composition isotherms and thermodynamic properties of $\mathrm{TiF}_{3}$-enhanced $\mathrm{Na}_{2} \mathrm{LiAlH}_{6}$. J. Alloys Compd. 2005, 397, 135-139. [CrossRef]

245. Graetz, J.; Lee, Y.; Reilly, J.J.; Park, S.; Vogt, T. Structures and thermodynamics of the mixed alkali alanates. Phys. Rev. B 2005, 71, 184115. [CrossRef]

246. Sørby, M.H.; Brinks, H.W.; Fossdal, A.; Thorshaug, K.; Hauback, B.C. The crystal structure and stability of K2NaAlH6. J. Alloys Compd. 2006, 415, 284-287. [CrossRef]

247. Mamatha, M.; Weidenthaler, C.; Pommerin, A.; Felderhoff, M.; Schüth, F. Comparative studies of the decomposition of alanates followed by in situ XRD and DSC methods. J. Alloys Compd. 2006, 416, 303-314. [CrossRef]

248. Varin, R.A.; Jang, M. The effects of graphite on the reversible hydrogen storage of nanostructured lithium amide and lithium hydride $\left(\mathrm{LiNH}_{2}+1.2 \mathrm{LiH}\right)$ system. J. Alloys Compd. 2011, 509, 7143-7151. [CrossRef]

249. Paskevicius, M.; Sheppard, D.A.; Buckley, C.E. Thermodynamic Changes in Mechanochemically Synthesized Magnesium Hydride Nanoparticles. J. Am. Chem. Soc. 2010, 132, 5077-5083. [CrossRef] [PubMed]

250. Kenisarin, M.M. High-temperature phase change materials for thermal energy storage. Renew. Sustain. Energy Rev. 2010, 14, 955-970. [CrossRef] 
251. Wagman, D.D.; Evans, W.H.; Parker, V.B.; Schumm, R.H.; Halow, I.; Bailey, S.M.; Churney, K.L.; Nuttall, R.L. The NBS tables of chemical thermodynamic properties. Selected values for inorganic and C1 and C2 organic substances in SI units. J. Phys. Chem. Ref. Data 1982, 11 (Suppl. 2). [CrossRef]

252. Gavrichev, K.S. Heat Capacity and Thermodynamic Properties of Inorganic Compounds Containing Tetrahedral Anions (BH-4, AlH-4, GaH-4, BF-4, ClO-4, BrO-4, and IO-4). Inorg. Mater. 2003, 39, S89-S112. [CrossRef]

253. Juza, R.; Opp, K. Metallamide und Metallnitride, 24. Mitteilung. Die Kristallstruktur des Lithiumamides. Z. Anorg. Allg. Chem. 1951, 266, 313-324. [CrossRef]

254. Stasinevich, D.S.; Egorenko, G.A. Thermographic investigation of alkali metal and magnesium tetrahydroborates at pressures up to $10 \mathrm{~atm}$. Russ. J. Inorg. Chem. 1968, 13, 341-343.

255. Paskevicius, M.; Ley, M.B.; Sheppard, D.A.; Jensen, T.R.; Buckley, C.E. Eutectic melting in metal borohydrides. Phys. Chem. Chem. Phys. 2013, 15, 19774-19789. [CrossRef] [PubMed]

256. Liu, Z.-K.; Zhong, Y.; Schlom, D.G.; Xi, X.X.; Li, Q. Computational thermodynamic modeling of the Mg-B system. Calphad 2001, 25, 299-303. [CrossRef]

257. Bogdanović, B.; Bohmhammel, K.; Christ, B.; Reiser, A.; Schlichte, K.; Vehlen, R.; Wolf, U. Thermodynamic investigation of the magnesium-hydrogen system. J. Alloys Compd. 1999, 282, 84-92. [CrossRef]

258. Bogdanović, B.; Hofmann, H.; Neuy, A.; Reiser, A.; Schlichte, K.; Spliethoff, B.; Wessel, S. Ni-doped versus undoped $\mathrm{Mg}-\mathrm{MgH}_{2}$ materials for high temperature heat or hydrogen storage. J. Alloys Compd. 1999, 292, 57-71. [CrossRef]

259. Marcus, Y. Chapter 3-High Melting Salts in Ionic Liquid Properties: From Molten Salts to RTILs; Springer International Publishing: Cham, Switzerland, 2016.

260. Sohal, M.S.; Ebner, M.A.; Sabharwall, P.; Sharpe, P. Engineering Database of Liquid Salt Thermophysical and Thermochemical Properties; Idaho National Laboratory (INL): Idaho Falls, ID, USA, 2010.

261. Lehman, P.A.; Chamberlin, C.E. Design of a photovoltaic-hydrogen-fuel cell energy system. Int. J. Hydrogen Energy 1991, 16, 349-352. [CrossRef]

262. Vanhanen, J.P.; Lund, P.D.; Hagström, M.T. Feasibility study of a metal hydride hydrogen store for a self-sufficient solar hydrogen energy system. Int. J. Hydrogen Energy 1996, 21, 213-221. [CrossRef]

263. Gray, E.M.; Webb, C.J.; Andrews, J.; Shabani, B.; Tsai, P.J.; Chan, S.L.I. Hydrogen storage for off-grid power supply. Int. J. Hydrogen Energy 2011, 36, 654-663. [CrossRef]

264. Lototskyy, M.V.; Tolj, I.; Pickering, L.; Sita, C.; Barbir, F.; Yartys, V. The use of metal hydrides in fuel cell applications. Prog. Nat. Sci. Mater. Int. 2017, 27, 3-20. [CrossRef]

265. Lu, L.; Han, X.; Li, J.; Hua, J.; Ouyang, M. A review on the key issues for lithium-ion battery management in electric vehicles. J. Power Sources 2013, 226, 272-288. [CrossRef]

266. Vetter, J.; Novák, P.; Wagner, M.R.; Veit, C.; Möller, K.-C.; Besenhard, J.O.; Winter, M.; Wohlfahrt-Mehrens, M.; Vogler, C.; Hammouche, A. Ageing mechanisms in lithium-ion batteries. J. Power Sources 2005, 147, $269-281$. [CrossRef]

267. Armand, M.; Tarascon, J.-M. Building better batteries. Nature 2008, 451, 652-657. [CrossRef] [PubMed]

268. Khalil, Y.F.; Opalka, S.M.; Laube, B.L. Experimental and theoretical investigations for mitigating $\mathrm{NaAlH}_{4}$ reactivity risks during postulated accident scenarios involving exposure to air or water. Process Saf. Environ. Prot. 2013, 91, 463-475. [CrossRef]

269. Chaise, A.; de Rango, P.; Marty, P.; Fruchart, D.; Miraglia, S.; Olivès, R.; Garrier, S. Enhancement of hydrogen sorption in magnesium hydride using expanded natural graphite. Int. J. Hydrogen Energy 2009, 34, 8589-8596. [CrossRef]

270. Maleki, H.; Howard, J.N. Effects of overdischarge on performance and thermal stability of a Li-ion cell. J. Power Sources 2006, 160, 1395-1402. [CrossRef]

271. Goodenough, J.B.; Park, K.-S. The Li-Ion Rechargeable Battery: A Perspective. J. Am. Chem. Soc. 2013, 135, 1167-1176. [CrossRef] [PubMed]

272. Soloveichik, G.L. Battery Technologies for Large-Scale Stationary Energy Storage. Annu. Rev. Chem. Biomol. Eng. 2011, 2, 503-527. [CrossRef] [PubMed]

273. Zaghib, K.; Dontigny, M.; Guerfi, A.; Charest, P.; Rodrigues, I.; Mauger, A.; Julien, C.M. Safe and fast-charging Li-ion battery with long shelf life for power applications. J. Power Sources 2011, 196, 3949-3954. [CrossRef] 
274. Uchida, H.; Naragaki, Y. Influence of the Cyclic Hydriding-Dehydriding Treatment on Pressure-Composition-Temperature Relations of the $\mathrm{LaNi}_{5}-\mathrm{H}$ System. Z. Phys. Chem. 1993, 179, 93-101. [CrossRef]

275. Bershadsky, E.; Josephy, Y.; Ron, M. Investigation of kinetics and structural changes in $\mathrm{TiFe}_{0.8} \mathrm{Ni}_{0.2}$ after prolonged cycling. J. Common Met. 1991, 172, 1036-1043. [CrossRef]

276. Etacheri, V.; Marom, R.; Elazari, R.; Salitra, G.; Aurbach, D. Challenges in the development of advanced Li-ion batteries: A review. Energy Environ. Sci. 2011, 4, 3243-3262. [CrossRef]

277. Urbanczyk, R.; Bathen, D.; Felderhoff, M.; Burfeind, J. HT-PEM fuel cell system with integrated complex hydride storage tank. In Parallel Sessions Book 4: Storage Systems/Policy Perspectives, Initiatives and Co-operations, Proceedings of the 18th World Hydrogen Energy Conference 2010 (WHEC2010), Essen, Germany, 16-21 May 2010; Stolten, D., Grube, T., Eds.; Forschungszentrum Jülich GmbH: Jülich, Germany, 2010; pp. 177-183.

278. Farnes, J.; Vik, A.; Bokach, D.; Svendsen, T.; Schautz, M.; Geneste, X. Recent developments of regenerative fuel cell systems for satellites. In Proceedings of the 10th European Space Power Conference, Noordwijkerhout, The Netherlands, 13-17 April 2014; Available online: http:/ /www.esa-tec.eu/workspace/assets/files/ tdo0157-paper-regenerative-f-5504a3929eb6a.pdf (accessed on 16 October 2017).

279. Reissner, A.; Pawelke, R.H.; Hummel, S.; Cabelka, D.; Gerger, J.; Farnes, J.; Vik, A.; Wernhus, I.; Svendsen, T.; Schautz, M.; et al. Metal hydride hydrogen and heat storage systems as enabling technology for spacecraft applications. J. Alloys Compd. 2015, 645, S9-S13. [CrossRef]

280. Pfeifer, P.; Wall, C.; Jensen, O.; Hahn, H.; Fichtner, M. Thermal coupling of a high temperature PEM fuel cell with a complex hydride tank. Int. J. Hydrogen Energy 2009, 34, 3457-3466. [CrossRef]

281. Nasri, M.; Dickenson, D. Thermal Management of Fuel Cell-driven Vehicles using HT-PEM and Hydrogen Storage. In Proceedings of the Ninth International Conference on Ecological Vehicles and Renewable Energies, Monte-Carlo, Monaco, 25-27 March 2014; pp. 1-6.

282. Reddy, E.H.; Jayanti, S. Thermal Coupling Studies of a High Temperature Proton Exchange Membrane Fuel Cell Stack and a Metal Hydride Hydrogen Storage System. Energy Procedia 2012, 29, 254-264. [CrossRef]

283. Hu, J.; Fichtner, M.; Baricco, M. Preparation of Li-Mg-NH hydrogen storage materials for an auxiliary power unit. Int. J. Hydrogen Energy 2017, 42, 17144-17148. [CrossRef]

284. Delhomme, B.; Lanzini, A.; Ortigoza-Villalba, G.A.; Nachev, S.; de Rango, P.; Santarelli, M.; Marty, P.; Leone, P. Coupling and thermal integration of a solid oxide fuel cell with a magnesium hydride tank. Int. J. Hydrogen Energy 2013, 38, 4740-4747. [CrossRef]

285. Garrier, S.; Chaise, A.; de Rango, P.; Marty, P.; Delhomme, B.; Fruchart, D.; Miraglia, S. MgH $_{2}$ intermediate scale tank tests under various experimental conditions. Int. J. Hydrogen Energy 2011, 36, 9719-9726. [CrossRef]

286. Parra, D.; Gillott, M.; Walker, G.S. Design, testing and evaluation of a community hydrogen storage system for end user applications. Int. J. Hydrogen Energy 2016, 41, 5215-5229. [CrossRef]

287. Gkanas, E.I.; Makridis, S.S. Effective thermal management of a cylindrical $\mathrm{MgH}_{2}$ tank including thermal coupling with an operating SOFC and the usage of extended surfaces during the dehydrogenation process. Int. J. Hydrogen Energy 2016, 41, 5693-5708. [CrossRef]

288. Yiotis, A.G.; Kainourgiakis, M.E.; Kosmidis, L.I.; Charalambopoulou, G.C.; Stubos, A.K. Thermal coupling potential of Solid Oxide Fuel Cells with metal hydride tanks: Thermodynamic and design considerations towards integrated systems. J. Power Sources 2014, 269, 440-450. [CrossRef]

289. Schouwink, P.; Didelot, E.; Lee, Y.-S.; Mazet, T.; Černý, R. Structural and magnetocaloric properties of novel gadolinium borohydrides. J. Alloys Compd. 2016, 664, 378-384. [CrossRef]

290. Hansen, B.R.S.; Paskevicius, M.; Li, H.-W.; Akiba, E.; Jensen, T.R. Metal boranes: Progress and applications. Coord. Chem. Rev. 2016, 323, 60-70. [CrossRef]

291. McPhy Energy McPhy Energy. Available online: www.mcphy.com (accessed on 16 October 2017).

292. Huiberts, J.N.; Griessen, R.; Rector, J.H.; Wijngaarden, R.J.; Dekker, J.P.; de Groot, D.G.; Koeman, N.J. Yttrium and lanthanum hydride films with switchable optical properties. Nature 1996, 380, 231-234. [CrossRef]

(C) 2017 by the authors. Licensee MDPI, Basel, Switzerland. This article is an open access article distributed under the terms and conditions of the Creative Commons Attribution (CC BY) license (http:/ / creativecommons.org/licenses/by/4.0/). 